Volume 121

Issue 2 Dickinson Law Review - Volume 121, 2016-2017

10-1-2016

\title{
Rethinking Student Cell Phone Searches
}

Marc C. McAllister

Follow this and additional works at: https://ideas.dickinsonlaw.psu.edu/dlra

\section{Recommended Citation}

Marc C. McAllister, Rethinking Student Cell Phone Searches, 121 Dick. L. ReV. 309 (2016).

Available at: https://ideas.dickinsonlaw.psu.edu/dlra/vol121/iss2/2

This Article is brought to you for free and open access by the Law Reviews at Dickinson Law IDEAS. It has been accepted for inclusion in Dickinson Law Review by an authorized editor of Dickinson Law IDEAS. For more information, please contact lja10@psu.edu. 


\title{
Articles
}

\section{Rethinking Student Cell Phone Searches}

\section{Marc C. McAllister*}

\begin{abstract}
In Fourth Amendment analysis, warrants are often required to search for evidence of criminal wrongdoing. However, under the searchincident-to-arrest warrant exception, once an individual has been placed under custodial arrest, certain warrantless searches may follow, such as a search for weapons or evidence possibly within the arrestee's reach. In Riley v. California, 134 S. Ct. 2473 (2014), the Supreme Court unanimously rejected the proposed extension of the search-incident-toarrest exception to cell phones, thereby requiring a warrant to search a phone's digital contents. Although Riley recognized that arrestees have reduced expectations of privacy, the privacy concerns in a cell phone's digital data were simply too great to allow such data to be searched without judicial approval.

This article examines Riley's impact on searches of K-12 and college students' cell phones as an incident to a violation of law or school rule, and proposes heightened Fourth Amendment protections in both contexts. First, this article argues that although college students enjoy reduced Fourth Amendment protections when campus safety and

* Marc McAllister teaches courses and writes on topics involving criminal law and procedure. His articles have been published in respected journals such as the Cincinnati Law Review, Florida State Law Review, Hofstra Law Review, Seattle Law Review, and Case Western Reserve Law Review.
\end{abstract}


educational concerns predominate, those concerns do not apply to a cell phone's digital contents. Unlike a weapon hidden in a student's dorm room, a cell phone's digital data cannot harm anyone, and routinely inspecting such devices would not enhance the educational environment. Accordingly, this article contends that the cell phones of college students deserve the full protections of a warrant and probable cause, as in Riley. For K-12 students, this article proposes a solution that accounts for the unique privacy concerns in cell phones while simultaneously preserving the school system's need for freedom from judicial supervision. Thus, this article proposes that schools adopt an internal system of checks and balances marked by independent review of a school official's desire to search a student cell phone and documented reasons for performing the search.

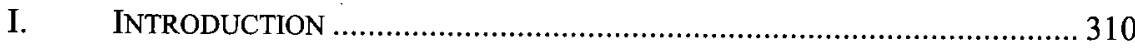

II. SEARCH INCIDENT TO ARREST EXCEPTION …………………............... 315

A. Search Incident to Arrest Exception Applied to the Home and to Vehicles

B. Search Incident to Arrest Exception Applied to Cell Phones: Riley v. California.

III. FOURTH AMENDMENT APPLIED TO K-12 STUDENTS ............................... 325

A. K-12 Students' Reduced Expectations of Privacy ......................... 325

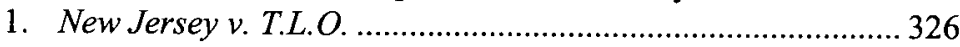

2. Safford United School District v. Redding …………………... 329

B. K-12 Student Cell Phone Searches: Pre-Riley Case Law ............. 332

1. Reasonable at its Inception..................................................... 332

2. Reasonable in Scope .......................................................... 337

IV. FOURTH AMENDMENT APPLIED TO COLLEGE STUDENTS..........................338

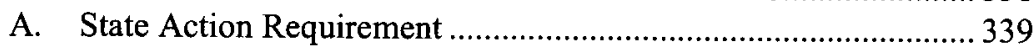

B. Reasonableness Requirement .............................................................. 341

V. K-12 AND COLLEGE STUDENT CELL PHONE SEARCHES AFTER RILEY .. 344

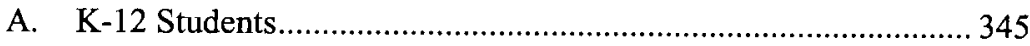

B. College Students ....................................................................... 350

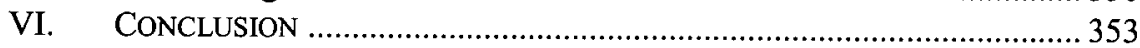

\section{INTRODUCTION}

Although just fifty-four words in length, the Fourth Amendment to the United States Constitution has spawned a vast array of case law and academic commentary. ${ }^{1}$ Not only is Fourth Amendment law

1. The Fourth Amendment provides: 
voluminous, it is also context-specific. ${ }^{2}$ As such, Fourth Amendment protections vary based on a variety of factors, including the level of intrusiveness of a particular investigative technique, the suspect's status, the location of the search, and the manner of investigation. Thus, a custodial arrest requires a greater degree of suspicion than does a suspect's brief detention; ${ }^{3}$ K-12 students enjoy less Fourth Amendment protection than adult citizens; ${ }^{4}$ searches conducted at the border require less suspicion of wrongdoing than searches outside the home; ${ }^{5}$ and a suspect's location may be determined, without judicial approval, via cell tower records, but may not be obtained without a warrant through a GPS device that police attach to the same suspect's vehicle. ${ }^{6}$ In the Fourth Amendment, context matters.

The right of the people to be secure in their persons, houses, papers, and effects, against unreasonable searches and seizures, shall not be violated, and no Warrants shall issue, but upon probable cause, supported by Oath or affirmation, and particularly describing the place to be searched, and the persons or things to be seized.

U.S. CoNsT. amend. IV.

2. The Supreme Court has recognized the context-specific nature of the Fourth Amendment. See, e.g., New Jersey v. T.L.O., 469 U.S. 325, 337 (1985) ("Although the underlying command of the Fourth Amendment is always that searches and seizures be reasonable, what is reasonable depends on the context within which a search takes place.").

3. Compare New York v. Harris, 495 U.S. 14, 18 (1990) (noting the "long... settled" rule that "a warrantless arrest in a public place [i]s permissible as long as the arresting officer had probable cause"), with Terry v. Ohio, 392 U.S. 1, 20-22 (1968) (authorizing a brief, temporary seizure of a person suspected of committing a crime on the basis of reasonable suspicion rather than probable cause).

4. Under United States v. Chadwick, 433 U.S. 1 (1977), adult citizens enjoy full Fourth Amendment protection in their closed containers, which require either a warrant or an applicable warrant exception to search. In the K-12 context, warrantless searches of lockers, purses, backpacks, cars, and clothing have all been upheld as reasonable based on a mere "reasonable suspicion" that the student at issue had violated either the law or school rules. See Bernard James, T.L.O. and Cell Phones: Student Privacy and Smart Devices After Riley v. California, 101 Iowa L. REv. 343, 350 (2015) (citing cases).

5. Compare United States v. Place, 462 U.S. 696, 707 (1983) (holding that the use of trained narcotics detection dogs at an international airport is not a Fourth Amendment "search," effectively allowing the investigative technique to be used without a warrant or probable cause), with Florida v. Jardines, 133 S. Ct. 1409, 1417-18 (2013) (deeming use of a drug-sniffing dog on the front porch of a suspect's home a Fourth Amendment "search," effectively requiring probable cause and a warrant, or some applicable warrant exception).

6. See Marc McAllister, GPS and Cell Phone Tracking: A Constitutional and Empirical Analysis, 82 U. CIN. L. REV. 207, 221-29 (2013) (comparing cases).

7. See Cornfield by Lewis v. Consol. High Sch. Dist. No. 230, 991 F.2d 1316, 1320-21 (7th Cir. 1993) (discussing various types of school searches and recognizing that "whether a search is 'reasonable' in the constitutional sense will vary according to the context of the search"). 
In Riley v. California, ${ }^{8}$ the United States Supreme Court sought to determine the precise Fourth Amendment protection owed an arrestee's cell phone. The Fourth Amendment generally requires police to obtain a warrant to search for evidence of criminal wrongdoing. ${ }^{9}$ However, under the warrant requirement's "search incident to arrest" exception, certain warrantless searches may occur once an individual has been placed under custodial arrest, such as a search for weapons or destructible evidence that may be within the arrestee's reach at the time of arrest. ${ }^{10}$ As long as the arrest is based on probable cause, ${ }^{11}$ the resulting search for weapons and destructible evidence requires no independent suspicion. ${ }^{12}$ Riley rejected application of this exception to cell phones found on arrestees, even though they could contain destructible evidence, and made clear that the substantial privacy interests inherent in the digital contents of a cell phone far outweigh the otherwise limited privacy rights enjoyed by arrestees. ${ }^{13}$

This article examines Riley's impact on searches of the digital contents of K-12 and college students ${ }^{14}$ cell phones as an incident to a violation of law or school policy. ${ }^{15}$ As of today, Riley requires probable cause and a warrant to search a cell phone's digital contents as an incident to an arrest, ${ }^{16}$ but neither safeguard is required to conduct the same search as an incident to a K-12 student's suspected violation of law

8. Riley v. California, 134 S. Ct. 2473 (2014).

9. Id. at 2482.

10. See People v. Chiagles, 142 N.E. 583, 584 (N.Y. 1923).

11. See New York v. Harris, 495 U.S. 14, 18 (1990).

12. See United States v. Robinson, 414 U.S. 218, 235 (1973) ("A custodial arrest of a suspect based on probable cause is a reasonable intrusion under the Fourth Amendment; that intrusion being lawful, a search incident to the arrest requires no additional justification. It is the fact of the lawful arrest which establishes the authority to search, and we hold that in the case of a lawful custodial arrest a full search of the person is not only an exception to the warrant requirement of the Fourth Amendment, but is also a 'reasonable' search under that Amendment."). When police conduct a warrantless search incident to arrest, they may search not only "the arrestee's person," but also "the area from within which he might gain possession of a weapon or destructible evidence." See Arizona v. Gant, 556 U.S. 332, 339 (2009).

13. See Riley, $134 \mathrm{~S}$. Ct. at 2485-91 (discussing the privacy concerns inherent in modern cell phones as compared to the privacy concerns at issue in more traditional searches of purely physical evidence); see also id. at 2488 (discussing the reduced expectations of privacy resulting from arrest).

14. In this article, the author collectively refers to both college and university students by use of the single term, "college students."

15. As used in this article, the term "cell phone" refers to the modern "smartphone" capable of sending text messages, taking photographs, accessing the Internet, and storing large amounts of data, among other functions. See Riley, $134 \mathrm{~S}$. Ct. at 2480, 2482 (noting that such phones were "unheard of ten years ago," but today "a significant majority of American adults now own such phones").

16. Id. at 2485 . 
or school policy. ${ }^{17}$ Thus, Riley and K-12 precedents are in tension, ${ }^{18}$ particularly in those instances where K-12 students are arrested on school grounds in possession of a cell phone. ${ }^{19}$ The law is somewhat less clear in regards to college student cell phone searches. However, as with K-12 students, courts have recognized reduced Fourth Amendment protections for college students as well. ${ }^{20}$

After weighing the pros and cons of extending Riley to the schoolhouse gates, this article arrives at the simple conclusion that, despite its narrow holding, Riley's sweeping pronouncements regarding the unique privacy concerns inherent in the modern cell phone demand reconsideration of the law governing cell phone searches of K-12 and college students. Riley stated, for example, that searches of cell phones are far more invasive than searches of the person and his effects, and thus disallowed warrantless searches of cell phones under circumstances that permit searches of the person and his effects. ${ }^{21}$ More importantly, Riley declared that the privacy protections owed modern cell phones are even greater than what we enjoy in our homes, the area that has traditionally received the most Fourth Amendment protection, ${ }^{22}$ thereby implying that cell phone searches - of any kind and in any place-are owed the

17. See infra Part III.A.

18. Other commentators have noted the tension between Riley and the K-12 precedents. See, e.g., James, supra note 4, at 344 (recognizing that because "Riley categorically makes the warrantless seizure and harvesting of the digital contents of smart devices unlawful absent additional justification by police,... [i]n education law, Riley sits uncomfortably alongside New Jersey v. T.L.O.").

19. Cf. Mabry v. Lee Cty., No. 1:13-CV-00214, 2016 WL 952102, at *4 (N.D. Miss. Mar. 9, 2016) (discussing the intersection between the Supreme Court's K-12 strip search case, Safford Unified Sch. Dist. No. 1 v. Redding, 557 U.S. 364 (2009), which found a student strip search to violate the Fourth Amendment, and Florence $v$. Bd. of Chosen Freeholders of Cty. of Burlington, 132 S. Ct. 1510.(2012), which permitted suspicionless strip searches of all arrestees committed to a detention facility's general population).

20. See infra Part III.B.

21. According to the Court in Riley, "[c]ell phones... place vast quantities of personal information literally in the hands of individuals. A search of the information on a cell phone bears little resemblance to the type of brief physical search [of an arrestee and his possessions] considered in Robinson. We therefore decline to extend Robinson to searches of data on cell phones, and hold instead that officers must generally secure a warrant before conducting such a search." Riley, $134 \mathrm{~S}$. Ct. at 2485 .

22. The United States Supreme Court has repeatedly emphasized the heightened Fourth Amendment protections in the home. See, e.g., Payton v. New York, 445 U.S. 573,585 (1980) (recognizing that "physical entry of the home is the chief evil against which the wording of the Fourth Amendment is directed"); Kyllo v. United States, 533 U.S. 27, 31 (2001) ("At the very core of the Fourth Amendment stands the right of a man to retreat into his own home and there be free from unreasonable governmental intrusion. With few exceptions, the question whether a warrantless search of a home is reasonable and hence constitutional must be answered no.") (internal citations and marks omitted). 
greatest possible constitutional protection. ${ }^{23}$ Finally, although Riley involved searches of arrestees, who have traditionally enjoyed "diminished privacy interests," the Court nevertheless imposed the protections of probable cause and a warrant due to the countervailing privacy concerns in cell phones, notwithstanding arrestees' diminished expectations of privacy. ${ }^{24}$ This approach can be applied to K-12 and college students as well, who, like arrestees, have also enjoyed diminished privacy interests and reduced Fourth Amendment protections and who, like adult arrestees, typically house a substantial amount of private information within their phones.

Although there are strong arguments for extending Riley to searches of K-12 and college students' cell phones, there are also powerful arguments for refusing to do so, particularly with respect to K-12 students, whose freedoms are necessarily curtailed due to the level of supervision required in public schools. After weighing the competing concerns, this article proposes heightened Fourth Amendment requirements in both contexts. With respect to K-12 students, this article advocates a slight change to existing law that would account for the unique privacy interests in cell phones while simultaneously preserving the educational system's ability to control the learning environment without undue judicial supervision. To achieve the necessary balance, this article recommends that schools adopt an internal system of checks and balances requiring a higher-level, independent review of a school official's desire to search a student cell phone, along with an administrative warrant that a head school official must sign before a student's cell phone may be searched.

Regarding college students, this article argues that although college students enjoy reduced expectations of privacy in certain instances, particularly in the realm of administrative inspections of college living quarters, the campus safety concerns that underlie such rulings do not apply to a cell phone's digital contents. Unlike a weapon that may be hidden in a student's dorm room, a cell phone's digital data cannot harm anyone. Moreover, unlike administrative sweeps of dorm rooms for health and safety purposes, it is difficult to imagine a scenario where college student cell phones could be reasonably "inspected" for a similar administrative purpose. For these reasons, this article argues that college students should be afforded the same protections in their cell phones

23. The Court in Riley declared that "a cell phone search would typically expose to the government far more than the most exhaustive search of a house." Riley, $134 \mathrm{~S}$. Ct. at 2491. This is because, according to the Court in Riley, "[a] phone not only contains in digital form many sensitive records previously found in the home; it also contains a broad array of private information never found in a home in any form." Id.

24. Id. at 2488. 
enjoyed by the adult arrestees in Riley, namely the full protections of a warrant and probable cause.

Before examining Riley's impact on student cell phone searches, Part II of this article outlines the search incident to arrest exception and its underlying rationale. Part III summarizes the leading K-12 Fourth Amendment cases, their theoretical underpinnings, and lower court cases involving searches of $\mathrm{K}-12$ student cell phones. Part IV examines searches of college students' cell phones and outlines the unique privacy rights college students enjoy. Part V examines Riley's impact on K-12 and college cell phone search law, considering arguments for and against extending Riley to those cases. Part VI concludes.

\section{SEARCH INCIDENT TO ARREST EXCEPTION}

For several hundred years, the law has recognized that a search of an arrestee's person and the immediately surrounding area into which he might reach to obtain a weapon or destroy evidence is permissible as an incident of the arrest, and thus may be conducted without a search warrant. $^{25}$ The justification for allowing this type of search is two-fold: ensuring officer safety as the suspect is taken into custody, and preventing the accused from destroying evidence that may be within his reach at the time of arrest. ${ }^{26}$

As with any warrant exception, identifying the underlying justification for the exception is critical, not only for understanding why the exception exists, but also because the justification itself determines how the warrantless search may unfold. ${ }^{27}$ As a general Fourth Amendment principle, warrantless searches must not only be reasonable

25. See Weeks v. United States, 232 U.S. 383, 392 (1914) (recognizing in dictum "the right on the part of the Government, always recognized under English and American law, to search the person of the accused when legally arrested to discover and seize the fruits or evidences of crime"); People v. Chiagles, 142 N.E. 583, 584 (N.Y. 1923) (recognizing, based on centuries of precedent, that a "[s]earch of the person becomes lawful when grounds for arrest and accusation have been discovered, and the law is in the act of subjecting the body of the accused to its physical dominion."); see also Akhil Reed Amar, Fourth Amendment First Principles, 107 HARV. L. REV. 757, 764 (1994) (recognizing that the right to conduct a warrantless search incident to arrest dates back centuries).

26. See United States v. Robinson, 414 U.S. 218, 232 (1973). Regarding the officer safety rationale, writing in 1923, Justice Cardozo noted, "[t]he peace officer empowered to arrest must be empowered to disarm," adding that "[i]f he may disarm, he may search [the arrestee's person], lest a weapon be concealed." Id. (quoting Chiagles, 142 N.E. at 584).

27. See Terry v. Ohio, 392 U.S. 1, 18-19 (1968) (recognizing that "[ $t]$ he scope of [a warrantless] search must be 'strictly tied to and justified by' the circumstances which rendered its initiation permissible."). 
in their inception, they must also be reasonable in scope. ${ }^{28}$ In the particular context of a search incident to arrest, the lawful arrest itself triggers the right to search the arrestee for weapons or destructible evidence, thereby justifying the warrantless search. ${ }^{29}$ The scope of that search, including exactly where the arresting officer may search for weapons or destructible evidence, in turn depends on the likelihood an arrestee could access the area the officer seeks to search. ${ }^{30}$ Accordingly, when considering the extent of a government official's search and seizure powers under a particular warrant exception-not only in the arrest context but also in the $\mathrm{K}-12$ and college environments-it is critical to understand the exception's underlying rationale.

\section{A. Search Incident to Arrest Exception Applied to the Home and to Vehicles}

For the past several decades, the Supreme Court has struggled to define the precise scope of a permissible warrantless search incident to arrest. $^{31}$ In Chimel v. California, ${ }^{32}$ a 1969 search incident to arrest case,

28. See id. at 28-29 ("The manner in which the seizure and search were conducted is ... as vital a part of the inquiry as whether they were warranted at all. The Fourth Amendment proceeds as much by limitations upon the scope of governmental action as by imposing preconditions upon its initiation."). The Supreme Court has consistently acknowledged the scope of search principles set forth in cases like Terry $v$. Ohio and the K-12 search cases. See Horton v. California, 496 U.S. 128, 139-140 (1990) (discussing cases recognizing that a warrantless search must be circumscribed by the exigencies which justify its initiation).

29. See Robinson, 414 U.S. at 235.

30. See Arizona v. Gant, 556 U.S. 332, 339 (1978). See also id. at 341-43 (recognizing that the justifications underlying the search incident to arrest exception "authorize[] police to search a vehicle incident to a recent occupant's arrest only when the arrestee is unsecured and within reaching distance of the passenger compartment at the time of the search"). Scope of search principles also include a time element. Thus, once the circumstances that justify the warrantless search terminate, the search itself must terminate. A warrantless search justified by an exigency, for example, is no longer permissible once the exigency has ended. See, e.g., Mincey v. Arizona, 437 U.S. 385, 388-94 (1978) (finding that for the exigency in the case, "the need to look for injured persons" defined the scope of the permissible warrantless search and also demarcated its end point, such that once the exigency had ended, the right to search without a warrant ended as well); Warden v. Hayden, 387 U.S. 294, 297-300 (1967) (in a case of hot pursuit where police followed a robbery suspect into a particular home, finding that the exigent circumstances warrant exception applied such that the particular exigency-hot pursuit of an armed robber-both justified the warrantless entry into the home and defined the defined the scope of the permissible warrantless search that followed; as such, the officers had the right to search any place in the home where the armed robber, his weapons, or anyone else who might interfere with the arrest could be found, but their right to search without a warrant ended once the exigency ended).

31. See Riley v. California, 134 S. Ct. 2473, 2482-83 (2014).

32. Chimel v. California, 395 U.S. 752 (1969). 
the Court explicitly tied the scope of the search to its underlying justifications, which illustrates the modern approach to such cases.

In Chimel, police arrested a man inside his home and as an incident to his arrest-i.e., without a search warrant-conducted a search of his entire three-bedroom house. ${ }^{33}$ During their nearly hour-long search, officers opened drawers and inspected their contents, discovering numerous incriminating items later used to prosecute and convict the arrestee. $^{34}$ The Supreme Court granted certiorari in the case to resolve "whether the warrantless search of the [arrestee's] entire house can be constitutionally justified as incident to that arrest." 35 Tying the scope of the permissible warrantless search to its underlying justification, the Court declared that "[a] search ... incident to a lawful arrest [is] a strictly limited right [that] grows out of the inherent necessities of the situation at the time of the arrest." 36 Thus, the Court held that although it is reasonable to search the actual "area into which an arrestee might reach in order to grab a weapon or evidentiary items,",37 it is not reasonable to expand the scope of that warrantless search to encompass "any room other than that in which an arrest occurs" or "the desk drawers or other closed or concealed areas in that room itself." 38 Rather, "[s]uch searches ... may be made only under the authority of a search warrant [or applicable warrant exception]."39

Over the next forty years, the Court decided a variety of cases applying Chimel to searches of recent car occupants who had been placed under arrest, as well as the vehicles from which they had recently departed. New York v. Belton ${ }^{40}$ and Arizona v. Gant ${ }^{41}$ are the two most notable cases in this area, which together reinforce the notion that warrants may be dispensed with only when the justifications for the warrant exception at issue apply.

In Belton, a New York police officer pulled over a car for excessive speeding. There were four men in the car, including defendant Belton. After pulling over the vehicle, the officer smelled marijuana and observed drug paraphernalia. At this time, the officer directed the men to exit the car, and placed them under arrest. The officer then searched the

33. Id. at 753-54.

34. See id. at 754 .

35. Id. at 755 .

36. Id. at 759 (quoting Trupiano v. United States, 334 U.S. 699, 705 (1948)).

37. Id. at 763 .

38. Id.

39. Id.

40. New York v. Belton, 453 U.S. 454 (1981).

41. Arizona v. Gant, 556 U.S. 332 (2009). 
four men, as well as the passenger compartment of the car where he found a jacket that contained cocaine. ${ }^{42}$

Before trial, Belton unsuccessfully moved to suppress the cocaine as the product of an unlawful search. On appeal, the Supreme Court sought to determine whether it was proper to search the interior of the automobile as an "incident to a lawful custodial arrest of its occupants." Setting forth what police later understood to be an automatic right to search a vehicle's passenger compartment under these circumstances, ${ }^{44}$ the Court declared that "when a policeman has made a lawful custodial arrest of the occupant of an automobile, he may, as a contemporaneous incident of that arrest, search the passenger compartment of that automobile," ${ }^{45}$ as well as any containers found therein. ${ }^{46}$ As a result, the Court upheld the search of the vehicle and jacket at issue. ${ }^{47}$

Belton's automatic right to search the passenger compartment of a vehicle as an incident to the arrest of one of its occupants rested on the "generalization," endorsed by the Belton Court, "that articles inside the relatively narrow compass of the passenger compartment of an automobile are in fact generally, even if not inevitably, within 'the area into which an arrestee might reach in order to grab a weapon or evidentiary ite[m]."48 Over the next thirty years, courts and commentators questioned the validity of this "generalization" and the resulting rule allowing warrantless vehicle searches even in cases where the passenger compartment is not actually within the arrestee's reach at the time of the search, which turned out to be common, as in the case of a suspect securely detained in a police car when the search is conducted. ${ }^{49}$

42. See Belton, 453 U.S. at $455-56$.

43. See id. at 459 .

44. See Gant, 556 U.S. at 349 (noting that, prior to 2009, police viewed the Belton search rule as "an entitlement"); Thornton v. United States, 541 U.S. 615, 625 (2004) (Scalia, J., concurring) (describing Belton as "a bright-line rule for arrests of automobile occupants, holding that, because the vehicle's entire passenger compartment is 'in fact generally, even if not inevitably,' within the arrestee's immediate control, a search of the whole compartment is justified in every case").

45. Belton, 453 U.S. at 460 . In a footnote, the majority declared that its holding was consistent with Chimel, as its ruling simply defined the scope of the "grabbing area" as it relates to a lawfully arrested recent car occupant. See id. at 460 n.3.

46. See id. at 460 . The Court deemed containers found within the passenger compartment immediately searchable as well because, according to the Court, "if the passenger compartment is within reach of the [typical] arrestee, so also will containers in it be within reach." Id. The Court further declared that such containers may be searched "whether... open or closed." Id. at 461. See also id. at 460 n.4 (defining the term "container").

47. See id. at 462-63.

48. See id. at 460 .

49. See, e.g., Thornton, 541 U.S. at 628-29 (Scalia, J., concurring) (stating that the "reported cases involving this precise factual scenario-a motorist handcuffed and secured in the back of a squad car when the search takes place-are legion," and 
The holes in Belton's logic eventually became the basis for overruling its automatic right to search and more strictly adhering to Chimel's officer safety and evidence preservation rationales, which occurred in 2009 in Gant. ${ }^{50}$ In Gant, police knew that Gant's driver's license had been suspended, for which there was a warrant for his arrest, and observed him pull into the driveway of a home they were investigating. Gant parked and exited his car, shut the door, and began to walk toward the home. One of the officers then approached Gant, meeting him about ten to twelve feet from his car, and arrested him for driving with a suspended license. ${ }^{51}$

After securing Gant in the back of a patrol car, police then searched Gant's vehicle and discovered a gun and cocaine inside, which Gant unsuccessfully sought to suppress. The Supreme Court later granted certiorari to resolve whether Belton authorized the warrantless search. ${ }^{52}$ Overruling Belton's automatic right to search the passenger compartment of a vehicle as an incident to a vehicle occupant's arrest, the Court ruled that the exception permits a warrantless search of a suspect's vehicle "only when the arrestee is [actually] unsecured and within reaching distance of the passenger compartment at the time of the search." Otherwise, the Court declared, such warrantless searches would be allowed even where an arrestee, such as Gant, is not truly within reaching distance of his car at the time of the search. ${ }^{54}$ Simply stated, "[i]f there is no possibility that an arrestee could reach into the area that law enforcement officers seek to search, both [Chimel] justifications for

concluding that "[i]f it was ever true that the passenger compartment is 'in fact generally, even if not inevitably,' within the arrestee's immediate control at the time of the search, it certainly is not true today").

50. See Arizona v. Gant, 556 U.S. 332, 350 (2009) ("The experience of the 28 years since we decided Belton has shown that the generalization underpinning the broad reading of that decision is unfounded. We now know that articles inside the passenger compartment are rarely 'within the area into which an arrestee might reach,' and blind adherence to Belton's faulty assumption would authorize myriad unconstitutional searches. The doctrine of stare decisis does not require us to approve routine constitutional violations.").

51. See id. at 335-36.

52. See id. at 341 .

53. Id. at 343 . In a separate section of the opinion, "[a]lthough it does not follow from Chimel," the Court expanded the right to search in this instance to circumstances where it is "reasonable to believe evidence relevant to the crime of arrest might be found in the vehicle." Id. at 343 (quoting Thornton, 541 U.S. at 632 (Scalia, J., concurring)). According to Justice Scalia, who advocated for the adoption of this standard in Thornton, a search on this basis is reasonable because "[ $t]$ he fact of prior lawful arrest distinguishes the arrestee from society at large, and distinguishes a search for evidence of his crime from general rummaging," and "it is not illogical to assume that evidence of a crime is most likely to be found where the suspect was apprehended." Thornton, 541 U.S. at 630 (Scalia, J,, concurring).

54. Gant, 556 U.S. at 343. 
the search-incident-to-arrest exception are absent and the rule does not apply." $" 55$

Decided five years before Riley, Gant is significant in its affirmation of the principle that warrants may be dispensed with only when the justifications for the warrant exception at issue apply, at which point the governmental interests in dispensing with a warrant are fully in play, a principle that should be carried forward to K-12 and college student cell phone search cases. As noted, underlying the search incident to arrest exception is the assumption that a custodial arrest provides the arrestee an incentive to destroy evidence or use any available weapon to resist arrest. This rationale, in turn, determines what police may search for as an incident to arrest, defines where they may search, and designates how long they may search. Whether digital evidence contained within an arrestee's cell phone falls within the scope of such a warrantless search became the issue in Riley. ${ }^{56}$

\section{B. Search Incident to Arrest Exception Applied to Cell Phones: Riley v. California}

Riley is the most recent Supreme Court case involving the search incident to arrest exception, and is perhaps the most significant for purposes of determining the constitutional protections that apply to the digital data contained within K-12 and college students' cell phones.

In Riley, the Court considered "whether the police may, without a warrant, search digital information on a cell phone seized from an individual who has been arrested." ${ }^{57}$ In Riley's case, one of two cases consolidated for appeal, Riley was stopped for driving with expired registration tags. ${ }^{58}$ Thereafter, officers learned that Riley's license had been suspended, permitting them to impound the car. Another officer then conducted a warrantless inventory search of the car and discovered concealed firearms, prompting Riley's arrest on firearm possession charges. ${ }^{59}$

After Riley was arrested, an officer searched him as an incident to the arrest and discovered items associated with the "Bloods" street gang.

55. Id. at 339. Notably, the Court in Gant recognized that "[b]ecause officers have many means of ensuring the safe arrest of vehicle occupants, it will be the rare case in which an officer is unable to fully effectuate an arrest so that a real possibility of access to the arrestee's vehicle remains." Id. at 343 n.4.

56. Riley v. California, 134 S. Ct. 2473, 2484 (2014) ("These cases require us to decide how the search incident to arrest doctrine applies to modern cell phones. ...").

57. Id. at 2480 .

58. See id. For brevity's sake, the facts of Riley's companion case are not summarized here. For a summary of those facts, see $i d$. at $2480-82$.

59. See id. 
He also seized a cell phone from Riley's pants pocket, searched its contents, and discovered some words on the phone - presumably in text messages or contacts list - preceded by "CK," a label he associated with the term "Crip Killers," a slang term for members of the Bloods gang. About two hours later, again acting without a warrant, another officer examined the contents of Riley's phone for evidence of gang-related activity. ${ }^{60}$ On the phone, the officer discovered videos in which men yelled the moniker "Blood," along with photographs of Riley standing in front of a car that had been involved in a recent shooting. ${ }^{61}$ Riley was then charged with various crimes associated with that earlier shooting, including firing at an unoccupied vehicle, assault, and attempted murder. ${ }^{62}$

Before trial, Riley moved to suppress the evidence obtained from his cell phone, arguing that those searches required a warrant. ${ }^{63}$ The trial court denied Riley's motion and officers testified at trial about the incriminating videos and photographs found on Riley's phone, some of which were admitted into evidence. ${ }^{64}$ Riley was then convicted of all three counts and received an enhanced sentence of fifteen years to life in prison. $^{65}$ The California Court of Appeal affirmed the conviction and ruled that the digital contents of a cell phone found on an arrestee's person may be searched without a warrant under the search incident to arrest exception. After the California Supreme Court denied Riley's petition for review, the United States Supreme Court granted certiorari to review the matter. ${ }^{66}$

The Supreme Court began its analysis by noting that smart phones are only a few years old, and thus lack "precise guidance from the founding era" as to whether they may be searched without a warrant. ${ }^{67}$ For this reason, the Court applied the Fourth Amendment's reasonableness balancing test to determine the appropriate constitutional protection, ${ }^{68}$ essentially the same test applied in the $\mathrm{K}-12$ and college student search cases. ${ }^{69}$ This test, the Court noted, required it to assess "on the one hand, the degree to which [the search] intrudes upon an

60. See id. at $2480-81$.

61. Id. at 2481.

62. Id.

63. See id.

64. See id. (describing the California court proceedings).

65. Id.

66. See Riley, $134 \mathrm{~S}$. Ct. at 2482.

67. Id. at 2484 .

68. See id.

69. See New Jersey v. T.L.O., 469 U.S. 325, 341 (1985) (explaining that "the legality of a search of a student should depend simply on the reasonableness, under all the circumstances, of the search"). 
individual's privacy and, on the other, the degree to which it is needed for the promotion of legitimate governmental interests."70

Examining the governmental interests at stake, the Court acknowledged that the two risks identified in Chimel-harm to officers and possible destruction of evidence-are not truly present when digital data is searched. ${ }^{71}$ First, the Court found that digital data stored on a cell phone cannot harm anyone, such that searching a cell phone's data cannot be justified by safety concerns. ${ }^{72}$ Next, regarding Chimel's evidence destruction rationale, the Court noted that "once law enforcement officers have secured a cell phone, there is no longer any risk that the arrestee himself will be able to delete incriminating data from the phone," thereby making a warrantless search of the phone's digital data unreasonable. ${ }^{73}$

On the other side of the scale, the Court examined the privacy interests of arrestees. The Court acknowledged that arrestees enjoy "diminished privacy interests," but declared that when "privacy-related concerns are weighty enough," a search involving an arrestee may still require a warrant. ${ }^{74}$ Examining the cell phone's unique privacy interests, the Court distinguished a search of a cell phone's digital data from searches of other personal items carried by arrestees, stating that "[m]odern cell phones, as a category, implicate privacy concerns far beyond those implicated by the search of a cigarette pack, a wallet, or a purse." 75 As such, although a search of physical items found on an arrestee can be said to involve "no substantial additional intrusion on privacy beyond the arrest itself," extending that reasoning to digital data is unwarranted. ${ }^{76}$

Delving deeper into the unique privacy concerns inherent in a cell phone's digital data, the Court declared that modern cell phones are "minicomputers" capable of being used as a telephone, camera, video player, rolodex, calendar, tape recorder, library, diary, album, television, map, or newspaper. ${ }^{77}$ Cell phones also have "immense storage capacity,"

70. Riley, 134 S. Ct. at 2484.

71. See id. at $2484-85$.

72. Id. at 2485 .

73. Id. at 2486. This is true, according to the Court, despite the possibility of "remote wiping," which occurs when a third party erases a phone's stored data remotely. The Court was also not troubled by the possibility of encryption, which is a security feature that some modern cell phones use that renders a phone all but "unbreakable" unless police know the password. According to the Court, no evidence suggests that either problem is prevalent. Moreover, law enforcement already possess specific means of responding to these threats. See id. at 2486-87.

74. Id. at 2488 .

75. Id. at $2488-89$ (emphasis added).

76. See id. at 2489.

77. See id. 
typically allowing the user to store millions of pages of text, thousands of pictures, or hundreds of videos. ${ }^{78}$ Also, the Court noted that a cell phone contains many distinct types of private information, such as prescriptions and bank statements that collectively reveal a great deal more about an individual's private life than any isolated record. ${ }^{79}$ According to the Court, "the sum of an individual's private life can be reconstructed through a thousand photographs labeled with dates, locations, and descriptions," whereas "the same cannot be said of a photograph or two of loved ones tucked into a wallet." 80

Next, the Court found it significant that the data on a cell phone often dates back to its purchase, making it capable of conveying a rich history of information. ${ }^{81}$ The data on a cell phone could, for example, reveal a person's Internet search and browsing history over a lengthy period of time. ${ }^{82}$ Likewise, cell phone data could show the user's precise location at various moments in time, enabling police to reconstruct someone's movements in the past. ${ }^{83}$ Mobile application software, or "apps," could also reveal a great deal of information about all aspects of a person's life, such as political and religious affiliations, addictions, and finances. ${ }^{84}$ Finally, the Court noted that the prevalence of remote data storage, or "cloud computing," magnifies the privacy interests at stake, as searching a cell phone may enable police to access additional files stored in the cloud. According to the Court, this "would be like finding a key in a suspect's pocket and arguing that it allowed law enforcement to unlock and search a house," 85 which contradicts general Fourth Amendment principles requiring individualized and targeted suspicion. ${ }^{86}$ When all these distinct privacy concerns are added to the scale, the result is that the privacy interests inherent in cell phone searches "dwarf" those at issue in the ordinary search incident to arrest, even exceeding those of the home. ${ }^{87}$

78. See id.

79. See id.

80. Riley, 134 S. Ct. at 2489.

81. See id.

82. See id. at 2490.

83. See id.

84. See id.

85. See id. at 2491.

86. See Messerschmidt v. Millender, 132 S. Ct. 1235, 1252-56 (2012) (Sotomayor, J., dissenting) (reviewing the purpose of the Fourth Amendment's warrant clause of protecting against general searches and complaining that officers, by their own admission, engaged in a "fishing expedition for evidence of unidentified criminal activity committed by unspecified persons," which "was the very evil the Fourth Amendment was intended to prevent").

87. See Riley, $134 \mathrm{~S}$. Ct. at 2490-91 (declaring that "a cell phone search would typically expose to the government far more than the most exhaustive search of a house" 
As it pertains to K-12 and college student cell phone searches, the Riley Court's analysis is significant in four respects. First, although Riley's holding is narrow, the majority of its opinion is devoted to espousing the unique and pervasive privacy concerns inherent in the modern cell phone. Through its summary of the types of private information cell phones contain, the Court left no doubt that cell phones enjoy unique Fourth Amendment protection. As such, despite its narrow holding, Riley's broader pronouncements should not be disregarded when considering cell phone searches of K-12 and college students.

Second, to analyze the cell phone search at issue, which lacked any founding era guidance, the Riley Court applied the Fourth Amendment's reasonableness balancing test and simply weighed the government's interests against the privacy concerns at stake. This same test is often applied in the $\mathrm{K}-12$ and college student cases, and Riley strongly indicates that cell phone searches in the K-12 and college contexts will continue to be governed by a reasonableness analysis due to the same lack of founding era guidance.

Third, although the Riley Court acknowledged that arrestees enjoy "diminished privacy interests," the Court determined that the digital data contained within arrestees' cell phones may not be searched absent probable cause and a warrant. ${ }^{88}$ According to Riley, the significant privacy interests at stake in the modern cell phone's digital contents are more than enough to offset the otherwise reduced privacy interests of arrestees. This same rationale can arguably be applied to K-12 and college students, who have likewise enjoyed diminished privacy rights.

Finally, the Court rejected the Government's proposed rule that would restrict the scope of a warrantless cell phone search to the particular areas of the phone where information relevant to the crime of arrest, the arrestee's identity, or officer safety might be discovered. ${ }^{89}$ The Government argued that this proposed rule would prevent rummaging for evidence of unrelated crimes. ${ }^{90}$ Under its proposal, the Government explained, police would be empowered to search a phone's contacts list, call logs, text messages, and e-mails when doing so would enable police to determine the suspect's identity or information regarding the offense of arrest, as in the case of an arrested drug trafficker. ${ }^{91}$ The

because a phone contains not only "many sensitive records previously found in the home," but also "a broad array of private information never found in a home in any form....").

88. See id. at $2488,2493$.

89. See id. at 2492.

90. See Brief for Petitioner at 51, United States v. Wurie, 134 U.S. 999 (2014) (No. 13-212), 2014 WL 828012.

91. Id. at 52-53. 
Court rejected this approach, however, because of its potential to uncover private information having nothing to do with the Chimel justifications of officer safety and evidence destruction. The Court further noted that, as a practical matter, "officers would not always be able to discern in advance what information would be found where." 92

This final aspect of Riley is significant because, despite endorsing a nearly identical framework in the $\mathrm{K}-12$ cases, where educators are permitted to conduct warrantless searches that are "reasonable in scope" in light of the evidence of unlawful activity or rules violations known to them at the time, ${ }^{93}$ the Court was reluctant to adopt a similar rule here. In other words, although the Government's proposed scope limitations fit comfortably with the underlying search incident to arrest justifications, the rule it proposed proved unworkable because of the potential to uncover extraneous private information unconnected to the legitimate objectives recognized in the search incident to arrest cases. This ruling reflects the Court's larger concern that it is extremely difficult for an officer (or educator) to limit the scope of a cell phone search to avoid uncovering protected information. As such, the ruling suggests that if warrantless cell phone searches are to be permitted in the K-12 and college contexts, they must occur under strict scope limitations.

\section{FOURTH AMENDMENT APPLIED TO K-12 STUDENTS}

\section{A. K-12 Students' Reduced Expectations of Privacy}

For decades, the Supreme Court has recognized that K-12 students' "Fourth Amendment rights... are different in public schools than elsewhere." 94 Historically, K-12 educators have stood in loco parentis with certain parental powers over their schoolchildren. ${ }^{95}$ Thus, while at school, just as at home, minor children are "subject, even as to their physical freedom, to the control of their [educator] guardians." 96 More recently, the Court has recognized that public school systems have unique custodial responsibilities that require certain leeway in carrying out their responsibilities "as guardian and tutor of children entrusted to [their] care." These unique custodial and tutelary responsibilities

92. Riley, 134 S. Ct. at 2492.

93. See New Jersey v. T.L.O., 469 U.S. 325, 341 (1985).

94. Vernonia Sch. Dist. 47J v. Acton, 515 U.S. 646, 656 (1995).

95. See id. at 655 (discussing the common law origins of this power).

96. Id.

97. See Bd. of Educ. of Indep. Sch. Dist. No. 92 of Pottawatomie Cty. v. Earls, 536 U.S. 822, 829-30 (2002). See also id. at 830 (recognizing that "[a] student's privacy interest is limited in a public school environment where the State is responsible for maintaining discipline, health, and safety."). 
"permit[] a degree of supervision and control that could not be exercised over free adults," including "enforcement of rules against conduct that would be perfectly permissible if undertaken by an adult." 99 As Fourth Amendment law has developed in the $\mathrm{K}-12$ setting, the need to permit flexibility in supervision and control of K-12 students has translated into relaxed search and seizure rules. ${ }^{100}$

\section{New Jersey v. T.L.O.}

Any discussion of the Fourth Amendment as it pertains to public school K-12 students must include New Jersey v. T.L.O. ${ }^{101}$ which set forth today's standard for assessing the legality of searches by public school officials. ${ }^{102}$

In T.L.O., a public high school teacher discovered two girls smoking in a restroom, one of whom was fourteen-year-old freshman, T.L.O. Because smoking in a restroom violated a school rule, the teacher took the girls to speak with Assistant Vice Principal Theodore Choplick. When T.L.O. denied the smoking allegations, and even claimed she did not smoke at all, Choplick opened her purse and discovered cigarettes. As Choplick reached into the purse to retrieve the cigarettes, he also discovered cigarette rolling papers, which he associated with marijuana. This discovery prompted him to search the purse even more thoroughly. After a more extensive search, Choplick discovered marijuana, a pipe, empty plastic bags, a large number of one-dollar bills, an apparent list of students who owed T.L.O. money, and letters that implicated T.L.O. in marijuana dealing. ${ }^{103}$ Thereafter, T.L.O. confessed to police that she had been selling marijuana. ${ }^{104}$ Based on the evidence seized from T.L.O.'s purse and her confession, the State brought delinquency charges against T.L.O., who then moved to suppress the evidence seized from her purse and her confession 'on the grounds that the search of her purse was unlawful. ${ }^{105}$

The New Jersey state courts divided on the legality of the purse search, and the United States Supreme Court granted certiorari to

98. Vernonia, 515 U.S. at 655.

99. New Jersey v. T.L.O., 469 U.S. 325, 339 (1985).

100. See M.M. v. Anker, 607 F.2d 588, 589 (2d Cir. 1979) (recognizing that "teachers have a unique relationship to their students, both in administering discipline as part of their educational function, and in protecting the well-being of all children in their care and custody," which in turn "justify greater flexibility when applying the Fourth Amendment in a school setting").

101. New Jersey v. T.L.O., 469 U.S. 325 (1985).

102. See id. at 328.

103. Id.

104. Id. at 328-29.

105. Id. at 329 . 
consider the issue. ${ }^{106}$ Applying the Fourth Amendment's "reasonableness" test, which "balance[s] the need to search against the invasion which the search entails," the Court examined the "individual's legitimate expectations of privacy and personal security" vis-à-vis "the government's need for effective methods to deal with breaches of public order." 107 On one side of the scale, the Court considered a child's expectations of privacy in articles of personal property brought into public schools and, on this issue, rejected the State's argument that school children have "virtually no legitimate expectation of privacy" in such articles. ${ }^{108}$ Rather, the Court found that "schoolchildren may find it necessary to carry with them a variety of legitimate, noncontraband items, and there is no reason to conclude that they have necessarily waived all rights to privacy in such items merely by bringing them onto school grounds." 109 On the other side of the scale, the Court considered "the substantial interest of teachers and administrators in maintaining discipline in the classroom and on school grounds," which, in the Court's view, "requires a certain degree of flexibility in school disciplinary procedures." 110

In considering how to "strike the balance between the schoolchild's legitimate expectations of privacy and the school's equally legitimate need to maintain an environment in which learning can take place,"111 the Court noted that "the school setting requires some easing of the restrictions to which searches by public authorities are ordinarily subject," "12 most notably, the warrant requirement. According to the Court, "[t]he warrant requirement... is unsuited to the school environment" because "requiring a teacher to obtain a warrant before searching a child suspected of an infraction of school rules (or of the criminal law) would unduly interfere with the maintenance of the swift and informal disciplinary procedures needed in the schools."113

106. See id. at 330-32 (describing its decision to hear the case not only to resolve the legality of the search at issue, but also to determine whether the exclusionary rule is the appropriate remedy in juvenile court proceedings for unlawful school searches). Before addressing the legality of the search, the Court had to first determine "whether [the Fourth] Amendment's prohibition on unreasonable searches and seizures applies to searches conducted by public school officials." The Court held that it does, for the simple reason that public school officials, just as law enforcement officers, are state agents and thus subject to the limits on state action imposed by the Fourteenth Amendment. See id. at 333-37.

107. Id. at 337 .

108. Id. at 338 .

109. Id. at 339 .

110. See id. at $339-40$.

111. T.L.O., 469 U.S. at 340 .

112. Id. at 340 .

113. Id. 
After dispensing with the warrant requirement, the Court considered whether "some modification of the level of suspicion of illicit activity" was appropriate for public school searches-specifically, whether a level of suspicion less demanding than probable cause would suffice. ${ }^{114}$ Citing the "substantial need of teachers and administrators for freedom to maintain order in the schools," 115 along with the need to permit educators "to regulate their conduct according to the dictates of reason and common sense" as opposed to "the niceties of probable cause," "116 the Court determined that probable cause was indeed not required. ${ }^{117}$ Rather, the Court declared, "the legality of the search of a student should depend simply on the reasonableness, under all the circumstances, of the search." 118

In what has become the reasonableness test courts employ in this area, the Court then set forth a twofold inquiry for determining the reasonableness of a search in this particular context, considering: (1) whether the action was justified at its inception; and (2) whether the search as actually conducted was reasonably related in scope to the circumstances which justified the interference. ${ }^{119}$ Regarding the first requirement, the Court declared that a search of a student by a teacher or other school official will, "[u]nder ordinary circumstances," be justified at its inception "when there are reasonable grounds for suspecting"-in other words, reasonable suspicion ${ }^{120}$ _."that the search will turn up evidence that the student has violated or is violating either the law or the rules of the school." 121 Regarding the second requirement, the Court stated that "such a search will be permissible in its scope when the measures adopted are reasonably related to the objectives of the search and not excessively intrusive in light of the age and sex of the student and the nature of the infraction."

114. See id. at $340-41$.

115. See id. at 341 .

116. See id. at 343.

117. See id. at 341 .

118. See id.

119. See id.

120. See id. at 345 (adopting the "reasonable suspicion" standard); see also Safford United Sch. Dist. v. Redding, 557 U.S. 364, 370 (2009) (affirming that T.L.O. "applied a standard of reasonable suspicion to determine the legality of a school administrator's search of a student"). In comparing probable cause with the lesser reasonable suspicion requirement, the Safford Court summarized "the required knowledge component of probable cause" as "rais[ing] a 'fair probability' or a 'substantial chance' of discovering evidence of criminal activity," and described "[t] $]$ he lesser standard for school searches" as "a moderate chance of finding evidence of wrongdoing." See Safford, 557 U.S. at 371.

121. See T.L.O., 469 U.S. at 342.

122. See id. 


\section{Safford United School District v. Redding}

Although the T.L.O. Court ultimately upheld the search of T.L.O.'s purse as reasonable in its inception and reasonable in scope ${ }^{123}$ nearly 25 years later in Safford United School District $v$. Redding, ${ }^{124}$ the Court struck down a strip search of a similar school child based on suspicion that she was supplying prescription medicines to schoolchildren for recreational consumption. Most importantly, the Court suggested in this decision that more intrusive searches of schoolchildren require greater scrutiny, possibly including higher levels of suspicion. ${ }^{125}$

In Safford, school officials received information that students were bringing prescription medication to school for recreational use, which, if true, would have violated school policy. ${ }^{126}$ One student, who was caught possessing pills, informed school officials that she had obtained the pills from thirteen-year-old classmate, Savana Redding. ${ }^{127}$ Savana later denied the allegations and consented to a search of her backpack, which produced no evidence of wrongdoing. ${ }^{128}$ At that point, a teacher and the school nurse asked Savana to remove her jacket, socks, shoes, pants, and t-shirt, so they could continue the search for pills. ${ }^{129}$ Finally, Savana was told to pull her bra out and to the side and shake it, and to pull out the elastic on her underpants, which exposed her breasts and pelvic area to inspection. $^{130}$ No pills were found during any of the searches. ${ }^{131}$

Thereafter, Savana's mother filed suit against the School District and various school officials for conducting an illegal "strip search" i32 in violation of Savana's Fourth Amendment rights. The individual defendants moved for summary judgment, which the District Court granted due to no Fourth Amendment violation. ${ }^{133}$ The Supreme Court later granted certiorari to consider the constitutionality of the search of Savana's backpack, outer clothing, underwear, and bra. ${ }^{134}$

\footnotetext{
123. See id. at 343-47.

124. Safford United Sch. Dist. v. Redding, 557 U.S. 364, 379 (2009).

125. See infra notes $142-47$ and accompanying text.

126. See Safford, 577 U.S. at 371-72.

127. Id. at 372 .

128. Id. at 368 .

129. Id. at 369 .

130. Id.

131. Id.

132. See id. at 374. In describing the search that occurred in this case, the Court stated that " $[t]$ he exact label for this ... intrusion is not important, though strip search is a fair way to speak of it." Id.

133. See id. at 369. This ruling came in the context of the defendants' qualified immunity defense. See id. (describing the rulings of the lower courts).

134. See id. at 370.
} 
The Court first determined that both the search of Savana's backpack and of her outer clothing were reasonable and justified by a reasonable suspicion of wrongdoing, which was based, in part, on the other student's identification of Savana as the source of pills found at the school. ${ }^{135}$ Regarding the backpack and outer clothing search, the Court declared:

If a student is reasonably suspected of giving out contraband pills, she is reasonably suspected of carrying them on her person and in [her backpack] .... . If [a] reasonable suspicion of pill distribution were not understood to support searches of outer clothes and backpack[s], it would not justify any search worth making. ${ }^{136}$

The search of Savana's underwear and bra, however, was a different matter. According to the Court, this search, which "exposed [Savana's] breasts and pelvic area to some degree," is "categorically distinct" from the backpack and outer clothing search, thus "requiring distinct elements of justification on the part of school authorities." 137 On this issue, the Court found that "the content of the suspicion failed to match the degree of intrusion." 138 Here, the Court emphasized that school officials had no factual basis for believing that Savana was actually hiding pills in her underwear, and "general background possibilities" of students hiding pills in such places were otherwise insufficient. ${ }^{139}$ The Court further noted that the pills themselves were relatively innocuous - common pain relievers equivalent to two Advil - and school officials did not suspect that individual students were receiving a large quantity of pills. ${ }^{140}$ Thus, "the combination of these deficiencies was fatal to finding the search reasonable."141

Ultimately, it is unclear whether the Safford Court would have upheld the strip search at issue based on a mere reasonable suspicion to believe Savana had been concealing pills in her undergarments, had there been facts directly supporting that possibility, or whether the Court would have required a heightened level of suspicion, such as probable cause. ${ }^{142}$ The Court concluded, for example, by clarifying that "the

135. See id. at 372-74.

136. Safford, 557 U.S. at 373-74.

137. See id. at 374.

138. See id. at 375 .

139. See id. at 376.

140. See id. at 375-76.

141. Id. at 377.

142. See generally Martin R. Gardner, Strip Searching Students: The Supreme Court's Latest Failure to Articulate A "Sufficiently Clear" Statement of Fourth Amendment Law, 80 Miss. L.J. 955 (2011) (discussing the uncertainties created by the Court's decision in Safford, and recognizing that in cases involving reasonable suspicion 
T.L.O. concern to limit a school search to reasonable scope requires the support of reasonable suspicion of danger or of resort to underwear for hiding evidence of wrongdoing before a search can reasonably make the quantum leap from outer clothes and backpacks to exposure of intimate parts." 143 The Court thereby implied that if the school officials had a mere reason to believe that Savana was truly hiding pills in her underwear, as opposed to probable cause, then the search of her undergarments would have been reasonable. ${ }^{144}$ Yet, in the very next sentence, the Court placed that specific type of search "in a category of its own," 145 and had earlier noted that some communities have deemed such searches "never reasonable" due to their particularly degrading nature and have entirely banned such searches "no matter what the facts may be." 146 Thus, it seems safe to say that the Safford Court ratified, and at a minimum recognized, that more intrusive searches are subject to greater constitutional scrutiny, even in the K-12 setting where school officials are given wide leeway to conduct searches. This particular view has been endorsed by lower courts ${ }^{147}$ and is a principle that may.

that a student has hidden evidence under her clothing, a strip search could still be unreasonable under the Fourth Amendment).

143. See Safford, 557 U.S. at 377 (emphasis added).

144. See id. at 370 (recognizing that the T.L.O. Court "applied a standard of reasonable suspicion to determine the legality of a school administrator's search of a student."); see also id. at 371 (comparing probable cause with the lesser reasonable suspicion requirement, and describing "[t]he lesser standard for school searches" as "a moderate chance of finding evidence of wrongdoing."). Cf. Arizona v. Gant, 556 U.S. 332,343 (2009) (extending the right to search a vehicle incident to arrest when it is "reasonable to believe evidence relevant to the crime of arrest might be found in the vehicle").

145. See Safford, 557 U.S. at 377.

146. See id at 375. Cf. Hearring v. Sliwowski, 872 F. Supp. 2d 647, 670-73 (M.D. Tenn. 2012), rev'd in part, 712 F.3d 275 (6th Cir. 2013) (discussing relevant school strip search cases and concluding, in the context of analyzing a qualified immunity defense, that "the fundamental dignity of a young person's body is so obvious and [cases decided] since 1984 provide more than fair warnings to school officials that such intrusive searches of students cannot be made by school officials without justification").

147. See, e.g., Cornfield by Lewis v. Consol. High Sch. Dist. No. 230, 991 F.2d 1316,1321 (7th Cir. 1993) (discussing the issue and concluding that "as the intrusiveness of the search of a student intensifies, so too does the standard of Fourth Amendment reasonableness." Thus, "[w] hat may constitute reasonable suspicion for a search of a locker or even a pocket or pocketbook may fall well short of reasonableness for a nude search."); Phaneuf v. Fraikin, 448 F.3d 591, 597 (2d Cir. 2006) (agreeing with the Seventh Circuit Court of Appeals' observation in Cornfield by Lewis that "as the intrusiveness of the search of a student intensifies, so too does the standard of Fourth Amendment reasonableness."); M.M. v. Anker, 607 F.2d 588, 589 (2d Cir. 1979) ("We are ... of the view that as the intrusiveness of the search intensifies, the standard of Fourth Amendment 'reasonableness' approaches probable cause, even in the school context. Thus, when a teacher conducts a highly intrusive invasion such as the strip search in this case, it is reasonable to require that probable cause be present."). But see Doe v. Champaign Cmty. Unit 4 Sch. Dist., No. 11-3355, 2015 WL 3464076, at *5, *6 
influence future searches of K-12 student cell phones in light of Riley's pronouncements regarding the extreme intrusiveness of such searches.

\section{B. K-12 Student Cell Phone Searches: Pre-Riley Case Law}

As noted, T.L.O. requires a school official's search of a $\mathrm{K}-12$ student to be both reasonable in its inception, typically requiring reasonable suspicion of wrongdoing, as well as reasonable in scope, requiring measures "reasonably related to the objectives of the search and not excessively intrusive in light of the age and sex of the student and the nature of the infraction." 148 Prior to the Riley decision, courts applied the T.L.O. requirements to a number of cases involving K-12 student cell phone searches.

\section{Reasonable at its Inception}

T.L.O. first requires a student cell phone search to be reasonable in its inception. ${ }^{149}$ Two recent cases involving this requirement as applied to K-12 student cell phone searches are particularly noteworthy: J.W. v. Desoto County School District ${ }^{150}$ which upheld the search of a student's cell phone based on a suspected violation of school policy; and G.C. v. Owensboro Public Schools, ${ }^{151}$ which reached the opposite result on similar facts.

$J . W$. involved a seventh-grade student in Mississippi, R.W., who was expelled for using his cell phone on school grounds. At the time, the school's Discipline Rule 2-6 prohibited students from possessing or using a cell phone in school. ${ }^{152}$ Nevertheless, R.W. opened his phone while in class to retrieve a text message. Upon observing R.W. using his cell phone, his teacher, Stephen Stafford, asked R.W. for the device.

(C.D. Ill. May 29, 2015) (interpreting Safford as requiring reasonable suspicion to conduct a strip search, or some "specific reason 'to suppose that [D.M.] was carrying [marijuana] in [the waistband of his] underwear," rather than probable cause); Cummerlander v. Patriot Preparatory Acad. Inc., 86 F. Supp. 3d 808, 819 (S.D. Ohio 2015) (discussing the reasonable suspicion requirement of T.L.O. and Safford as requiring "a moderate chance of finding evidence of wrongdoing," and one that turns on the "specificity of the information received" and the "reliability of its source," among other context-specific factors) (quoting Safford, 577 U.S. at 371).

148. See New Jersey v. T.L.O., 469 U.S. 325, 342 (1985).

149. See id.

150. See generally J.W. v. Desoto Cty. Sch. Dist., No. 2:09-cv-00155-MPM-DAS, 2010 WL 4394059 (N.D. Miss. Nov. 1, 2010).

151. See generally G.C. v. Owensboro Pub. Schs., 711 F.3d 623 (6th Cir. 2013).

152. See J.W., 2010 WL 4394059, at *4 ("Desoto County School District's Rule 2-6 lists the '[p]ossession of electronic equipment/device (beepers, telephone, etc.) without prior approval of the administration' as a Level II offense, with a maximum punishment of three days suspension."). 
R.W. then closed the phone and handed it to Stafford, who opened the phone and reviewed its stored photographs. One of the photos showed another middle-school student holding a B.B. gun. R.W. was then taken to the office of the principal, Kenneth Walker, who also examined the phone's contents. After reviewing the photographs, Walker and local Police Sergeant Nicholas Kennedy "accused R.W. of having gang pictures," for which he was immediately suspended. ${ }^{153}$ R.W.'s suspension later became an expulsion after a hearing at which Walker testified that he perceived R.W. as "a threat to school safety." 154 R.W.'s mother then filed suit, alleging that the search of R.W.'s phone violated the Fourth Amendment.

The court focused its analysis on the individual defendants in the case, consisting mostly of school officials, who presented a qualified immunity defense ${ }^{155}$ that required R.W. to prove they violated "clearly established rights of which a reasonable person would have known." "156 Applying this standard, the court found that not only is there no "clearly established" United States Supreme Court case law establishing that the search of R.W.'s phone was unlawful, "that law is actually quite favorable to the individual defendants" given the Supreme Court's deviation from the probable cause requirement in T.L.O. and endorsement of a more lenient reasonableness test. ${ }^{157}$

In analyzing the defendants' actions, the court found it "crucial" that R.W. was caught using his cell phone at school, while the school rule at issue prohibited only the mere possession of such devices on school grounds. ${ }^{158}$ Regarding the decision to search the phone once seized, the court reasoned:

Upon witnessing a student improperly using a cell phone at school, it strikes this court as being reasonable for a school official to seek to determine to what end the student was improperly using that phone. For example, it may well be the case that the student was engaged in some form of cheating, such as by viewing information improperly stored in the cell phone. It is also true that a student using his cell phone at school may reasonably be suspected of communicating with another student who would also be subject to disciplinary action for improper cell phone usage. ${ }^{159}$

153. See id. at $* 1$.

154. See id. at $* 2$.

155. See id. at*3.

156. See id. (citation omitted).

157. See id. at *4.

158. See id.

159. Id. 
For these reasons, the court found that the search of R.W.'s cell phone, including its photographs, was justified in its inception and reasonable in scope even though the defendants had no suspicion of wrongdoing other than the use of the phone to retrieve a text message. ${ }^{160}$

In contrast to J.W., the United States Court of Appeals for the Sixth Circuit, in G.C., struck down a similar cell phone search for lack of evidence to suspect the phone contained incriminating information. ${ }^{161}$ The student at issue, G.C., had a history of disciplinary problems throughout high school. ${ }^{162}$ During his freshman year, G.C. informed school officials that he suffered from anger and depression. On two occasions, once in the fall of 2007 and again in the fall of 2008 , G.C. even indicated that he was considering taking his life. ${ }^{163}$

In September 2009, a teacher observed G.C. texting in class, which violated the school's cell phone policy. ${ }^{164}$ G.C.'s teacher confiscated the phone and brought it to the assistant principal, Melissa Brown, who then read four text messages on the device. ${ }^{165}$ According to Brown, she read the text messages "to see if there was an issue with which I could help him so that he would not do something harmful to himself or someone else."166 Brown explained that she had these worries because she "was aware of previous angry outbursts from [G.C.] and that [he] had admitted to drug use in the past." "167 Brown also noted that she knew G.C. "drove a fast car and had once talked about suicide," adding that she "was concerned how [he] would further react to his phone being taken away and that he might hurt himself or someone else." 168

G.C. later filed suit for alleged violations of his First, Fourth, and Fifth Amendment rights. ${ }^{169}$ Thereafter, the District Court granted the defendants' motion for summary judgment as to all of G.C.'s federal

160. See id. Regarding whether the search of the phone was reasonable in scope, the Mississippi district court distinguished the case from a similar cell phone search case, Klump v. Nazareth Area Sch. Dist., 425 F. Supp. 2d 622 (E.D. Pa. 2006), and declared that "the decision by the school officials in this case to merely look at the photos on R.W.'s cell phone was far more limited, and far more justified, than that taken by the school officials in Klump," such that the search at issue in R.W.'s case was "not contrary to clearly established law." See id. at *5.

161. G.C. v. Owensboro Pub. Schs., 711 F.3d 623, 632 (6th Cir. 2013) (involving an issue of first impression for the Sixth Circuit Court of Appeals on "how the T.L.O. [test] applies to the search of a student's cell phone").

162. See id. at 626-27.

163. See id. at 627 .

164. See id. at 628 .

165. See id.

166. Id.

167. Id.

168. Id.

169: Id. G.C. also brought claims under the Kentucky Constitution. See id. 
claims, which G.C. appealed to the Sixth Circuit Court of Appeals. ${ }^{170}$ After reviewing the T.L.O. standards and relevant case law, including $J . W$, the court cautioned that not all infractions involving cell phones will involve "reasonable suspicion that a search will uncover evidence of further wrongdoing or of injury to the student or another,"171 adding that "using a cell phone on school grounds does not automatically trigger an essentially unlimited right enabling a school official to search any content stored on the phone that is not related either substantively or temporally to the infraction." 172

Turning to the search of G.C.'s phone, the court considered whether school officials had reasonable grounds to suspect that a search of G.C.'s phone would reveal evidence of improper activity in light of defendants' argument that G.C.'s documented drug abuse and suicidal thoughts justified the search. ${ }^{173}$ Rejecting defendants' argument, the court found that "general background knowledge of drug abuse or depressive tendencies, without more," does not allow a school official to search a student's cell phone. ${ }^{174}$

Highlighting the lack of evidence that G.C. was engaging in unlawful activity at the time of the search, or that he was contemplating injuring himself at that time, the court declared:

G.C. was sitting in class when his teacher caught him sending two text messages on his phone. When his phone was confiscated... G.C. became upset. The defendants have failed to demonstrate how anything in this sequence of events indicated to them that a search of the phone would reveal evidence of criminal activity, impending contravention of additional school rules, or potential harm to anyone in the school. On these facts, the defendants did not have a reasonable suspicion to justify the search at its inception. ${ }^{175}$

Absent evidence to suggest that G.C. was using his phone to effectuate additional rules violations, such as accessing the internet to look up test answers, the G.C. court was unwilling to allow school officials to fish for evidence of anything that might incriminate G.C.

G.C. and $J . W$. are difficult to reconcile. The students in each case were observed using their cell phones in class to send or receive text messages; yet, one court authorized a warrantless search of the phone's contents, including its photographs, whereas the other court found no

170. Id.

171. See G.C., 711 F.3d at $632-33$.

172. Id. at 633 .

173. Id. at 633-34.

174. Id.

175. Id. at 634 . 
basis to search the phone at all. Unlike the $J . W$. court, which found it reasonable for a school official to search a phone's contents to determine "to what end [a] student [is] improperly using [his] phone," and upheld a search of the phone's photographs even where officials had no basis for suspecting the student was accessing photos at the time, ${ }^{176}$ the G.C. court interpreted the first T.L.O. requirement more stringently, requiring more than "general background knowledge" suggesting possible prohibited uses of the phone. ${ }^{177}$ As such, the G.C. court found the phone search unreasonable at its inception, where the $J . W$. court found a similar search reasonable in all respects.

Although the cases are difficult to reconcile, J.W. involved the qualified immunity defense, which required the plaintiff to produce "clearly established" United States Supreme Court case law in his favor. ${ }^{178}$ Since the Supreme Court has not decided a case involving a search of a K-12 student's phone, this was a difficult standard for J.W. to meet. Moreover, the defendants' stated reason for searching the phone in G.C. was not persuasive, as it involved nothing in the student's present circumstances that would have given rise to a genuine suspicion to believe the phone contained incriminating information at that time. Rather, according to the school official who searched G.C.'s phone, she read G.C.'s texts "to see if there was an issue with which I could help him so that he would not do something harmful to himself or someone else." 179 This explanation does not fit comfortably with the T.L.O. requirement of a present factual basis for suspecting a search will produce evidence that the student has violated or is violating a school rule or the law. ${ }^{180}$ Regardless, it remains the case that T.L.O.'s first requirement mandates some factual basis to suspect a cell phone's contents may include incriminating evidence before it may be searched. Moreover, the precise evidence needed to create "reasonable suspicion" may vary, depending on the circumstances at issue. ${ }^{181}$

176. See J.W. v. Desoto Cty. Sch. Dist., No. 2:09-cv-00155-MPM-DAS, 2010 WL 4394059, at *4 (N.D. Miss. Nov. 1, 2010).

177. G.C., 711 F.3d at $633-34$.

178. J.W., 2010 WL 4394059 , at *3.

179. G.C., 711 F.3d at 628 .

180. See New Jersey v. T.L.O., 469 U.S. 325, 342 (1985).

181. Perhaps the best articulation of the reasonable suspicion standard occurred in Terry $v$. Ohio, which declared that a reasonable suspicion of criminal activity requires "specific and articulable facts which, taken together with rational inferences from those facts," would make an officer suspicious of criminal activity. See 392 U.S. 1, 21 (1968). Reasonable suspicion is less demanding than probable cause, see Safford United Sch. Dist. v. Redding, 557 U.S. 364, 371 (2009), but requires more than an "inarticulate hunch," Terry, 392 U.S. at 22. 


\section{Reasonable in Scope}

Along with being reasonable in its inception, T.L.O. requires a student cell phone search to be reasonably related in scope to the circumstances that justified the search in the first place. ${ }^{182}$ One case from the United States District Court for the Eastern District of Pennsylvania, Klump v. Nazareth Area School District, ${ }^{183}$ exemplifies how school officials can violate the Fourth Amendment when they do not properly limit the scope of a cell phone search.

In Klump, plaintiff Christopher Klump's high school had a policy that permitted students to carry, but not use or display, cell phones during school hours. ${ }^{184}$ According to the complaint's allegations, which the court accepted as true in resolving the defendant's motion to dismiss, Christopher's cell phone fell out of his pocket while in school and came to rest on his leg, prompting his teacher to confiscate the device. ${ }^{185}$ The teacher and an assistant principal then used the phone to call nine other students listed in Christopher's contacts list to determine whether they too were violating the cell phone policy. ${ }^{186}$ The school officials also accessed Christopher's text messages and voice mail, and had a conversation with Christopher's younger brother, while pretending to be Christopher, by using the cell phone's instant messaging feature. ${ }^{187}$

Feeling aggrieved, Christopher and his parents filed suit against the school district, superintendent, assistant principal, and teacher alleging that Christopher's Fourth Amendment rights were violated when his teacher and assistant principal accessed his phone number directory, voice mail, and text messages, and used the phone to call other students. ${ }^{188}$ In response, defendants argued that the Klumps could not establish a Fourth Amendment violation because the search was justified in its inception and was reasonable in scope. ${ }^{189}$

Rejecting the defendants' argument, the court found that, although seizing the phone was permissible given that Christopher had violated the school's policy prohibiting use or display of cell phones during school hours, school officials violated the Fourth Amendment by using the phone to call other students in order to generate evidence of other students' misconduct. ${ }^{190}$ To initiate such a search, T.L.O. requires

182. T.L.O., 469 U.S. at 341.

183. Klump v. Nazareth Area Sch. Dist., 425 F. Supp. $2 d 622$ (E.D. Pa. 2006).

184. Id. at 630 .

185. Id.

186. Id.

187. Id. at 627,630 .

188. Id. at 628-29.

189. See id. at 639 .

190. See id. at 640 . 
"reasonable grounds for believing that the search will turn up evidence that the student [i.e., Christopher Klump] has violated or is violating either the law or the rules of the school." ${ }^{\prime 191}$ Based on the facts alleged in the complaint, however, officials had no reason to suspect that a search of Christopher's phone would produce evidence that Christopher himself was violating another school policy; rather, they simply hoped to use the phone to entice other students' violations. ${ }^{192}$ Accordingly, the court found no basis for initiating a search. ${ }^{193}$

Although the Klump court's analysis focused on the reasonableness of the phone's search at its inception, the case nicely illustrates a cell phone search that went too far. Even if the Klump court had followed the reasoning of $J . W$. and found it reasonable to search Christopher's phone, in a more limited manner, to determine to what end Christopher was improperly using the phone (for example, whether he was using the phone to cheat on a test), the extensive search in Klump would have clearly exceeded the scope of any such authorized search. ${ }^{194}$ Thus, the case is a vivid example of the type of search T.L.O. does not permit.

\section{FOURTH AMENDMENT APPLIED to COLLEGE STUDENTS}

Unlike the $\mathrm{K}-12$ context, where the law is generally straightforward in regards to the basic T.L.O. requirements and their application in the typical K-12 search case, the law is more complex in the college campus setting, primarily for two reasons. First, the actions of certain officials are sometimes beyond Fourth Amendment restrictions by virtue of the fact that purely private action, no matter how unreasonable, is not subject to constitutional constraints. ${ }^{195}$ Second, many college officials do not

191. See id. at 640 (quoting New Jersey v. T.L.O., 469 U.S. $325,341-42$ (1985)) (emphasis added).

192. See id. at 640 .

193. See Klump, 425 F. Supp. $2 d$ at $640-41$.

194. See T.L.O., 469 U.S. at 342.

195. See, e.g., Skinner v. Ry. Labor Execs. Ass'n, 489 U.S. 602, 614 (1989) (recognizing that "[a]lthough the Fourth Amendment does not apply to a search or seizure, even an arbitrary one, effected by a private party on his own initiative, the Amendment protects against such intrusions if the private party acted as an instrument or agent of the Government"); Commonwealth v. Bair, No. 11-P-1381, 2012 Mass. App. Unpub. LEXIS 894, at *6 (Mass. App. Ct. July 7, 2012) (recognizing that "[t]here is no 'search and seizure' in the constitutional sense where 'evidence is seized by private parties who are not acting as agents of the police and subsequently turned over to the police"). For essentially this same reason, purely private action cannot form the basis for a 42 U.S.C. $\& 1983$ civil suit based on an alleged Fourth Amendment violation. See, e.g., English v. Univ. of Tulsa, No. 14-CV-0284-CVE-FHM, 2015 WL 4623942, at *1, *4-5 (N.D. Okla. Aug. 3, 2015) (dismissing plaintiff's 42 U.S.C. $\S 1983$ claim when campus security officers of the University of Tulsa, a private university, entered plaintiff's apartment without consent because the alleged Fourth Amendment violation was not committed by a person "acting under color of state law," noting specifically that 
typically engage in criminal investigations. Thus, even where there is state action, criminal evidence on a college campus is often inadvertently discovered while carrying out an administrative function, such as a routine health and safety inspection of a dorm room, which is usually a "reasonable" administrative search under the Fourth Amendment. In considering whether searching a college student's cell phone falls outside the Fourth Amendment's protective umbrella, it is therefore necessary to consider these two variables, and, most importantly, whether they apply in the typical college student cell phone search case.

\section{A. State Action Requirement}

A threshold issue in Fourth Amendment analysis is whether its protections apply at all, which depends, in part, on whether the allegedly unlawful action involved state action. Whether a private person should be deemed an agent of the government for Fourth Amendment purposes is determined by the totality of the circumstances. ${ }^{196}$ Most courts applying this test consider two primary factors: (1) "whether the government [directed] ... or acquiesced in, the intrusive conduct"; and (2) "whether the party performing the search intended to assist law enforcement efforts or to further his own ends." "197 Under this test, as government involvement in the search increases, the private searcher's intent becomes less important. ${ }^{198}$ Thus, obvious cases of state action include, for example, those where a local police officer requests a private university official to conduct a search of a suspect's dorm room and turn over any criminal evidence obtained. ${ }^{199}$ Where such government involvement is absent, as is typical in most college searches, the test essentially focuses on the primary purpose of the inspection.

In the college campus setting, inspections are usually intended to advance some administrative purpose, such as ensuring safety in dorm

"[p]rivate universities are considered private parties" under $\S 1983$ and First Circuit case law).

196. See Skinner, 489 U.S. at 614-15.

197. See Bryan R. Lemons, Public Education and Student Privacy: Application of the Fourth Amendment to Dormitories at Public Colleges and Universities, 2012 B.Y.U. EDUC. \& L.J. 31, 43 (2012).

198. Id. at 43.

199. See, e.g., Piazzola v. Watkins, 442 F.2d 284, 286, 289 (5th Cir. 1971) (striking down a dorm room search of certain Troy State students conducted by both local law enforcement officers and university officials, at the request and direction of the local police, and recognizing that a university regulation permitting administrative inspections of dorm rooms "cannot be construed or applied so as to give consent to a search for evidence for the primary purpose of a criminal prosecution"). See also State v. Keadle, 277 S.E.2d 456, 459 (N.C. Ct. App. 1981) (recognizing that "where a search is conducted by a private citizen, but only at the government's initiation and under their guidance, it is not a private search but becomes a search by the sovereign"). 
rooms, or to uncover evidence of a crime, such as drug dealing by a student. Given the obligation of colleges to provide a safe learning environment, searches conducted for administrative purposes are permissible, whereas those conducted for criminal investigative purposes are not. Translated into Fourth Amendment principles, cases thus hold that campus personnel who conduct inspections may or may not be state actors, regardless of whether they are on a public or private university campus, depending on the purpose of their inspection. ${ }^{200}$

Searches of dorm rooms conducted by resident assistants provide the most vivid example of the typical state action analysis. Take, for example, a case involving a resident assistant at a public university who discovers a stolen stereo in a student's dorm room while conducting standard maintenance inspections of the lighting in all rooms. The resident assistant seizes the stolen stereo, leaves the room, and delivers the stereo to police, who then use the stereo to initiate a theft prosecution. When the student later attempts to suppress the stolen stereo in his subsequent theft prosecution, he will almost certainly fail. This is true even though the inspection occurred on a public university campus and despite the fact that the resident assistant was carrying out his official duties as a public university representative at the time. ${ }^{201}$ Because the primary purpose of the inspection was administrative in nature, rather than to secure evidence of a crime, courts will find there is no state action and the Fourth Amendment does not apply. ${ }^{202}$ As a result, there is no need to analyze the reasonableness of any alleged Fourth Amendment action.

200. See, e.g., Medlock v. Trustees of Ind. Univ., No. 1:11-CV-00977-TWP-DKL, 2011 WL 4068453 (S.D. Ind. Sept. 13, 2011). The Medlock court concluded that routine health and safety inspection by Indiana University resident assistants did not constitute state action because although "the actions of the Resident Specialist in conducting the health and safety inspection serve [Indiana University] at large, ... they are not tainted with the degree of government authority that will implicate the Fourth Amendment. Both [resident assistants] were fulfilling their obligations as resident specialists when they happened to observe a tube of marijuana and a marijuana plant in Medlock's room. Their inspection of Medlock's room was not at the behest of the police, but in accordance with [the university's] health and safety regulations." Id. at *4.

201. This illustration is based on State v. Keadle, 277 S.E.2d 456 (N.C. Ct. App. 1981), which, on similar facts, held that the Fourth Amendment does not apply because the purpose of the inspection was not to secure evidence to be used in a criminal conviction. See id. at 460 .

202. See id. at 459-60 (reasoning that the research assistant was "motivated by reasons independent of a desire to secure evidence to be used in a criminal conviction," such that excluding the evidence in the student's subsequent criminal prosecution would serve no meaningful deterrent function, making "the $[\mathrm{F}]$ ourth $[\mathrm{A}]$ mendment and the exclusionary rule inapplicable"). 


\section{B. Reasonableness Requirement}

As it turns out, courts have often conflated the Fourth Amendment's state action requirement, which is a threshold issue impacting the applicability of the Amendment, and its "reasonableness" requirement, which applies only when deciding whether an actual Fourth Amendment action-a search or seizure-was unlawful. Nevertheless, determining whether the Fourth Amendment applies under either line of inquiry usually turns on the same variable: the primary purpose of the inspection. Regardless of whether the analysis focuses on state action or reasonableness, an inspection with a primary purpose of uncovering criminal evidence typically triggers the Fourth Amendment's warrant requirement, whereas one whose primary purpose is administrative, such as a routine dorm room inspection for campus safety purposes, does not. $^{203}$

One recent case involving a private university, Commonwealth $v$. Carr, ${ }^{204}$ demonstrates how either line of inquiry can lead to the same result on the ultimate issue of whether a Fourth Amendment violation occurred. Most importantly, the case further illustrates how additional searches beyond an initial administrative inspection that are designed to uncover evidence to be used in a criminal prosecution (such as a cell phone search) must be justified by their own independent suspicion, and

203. The distinction turns on whether the inspection is a reasonable exercise of the college's supervisory duty and obligation to maintain an effective learning environment. As one court explained:

The college does not stand, strictly speaking, in loco parentis to its students, nor is their relationship purely contractual in the traditional sense. The relationship grows out of the peculiar... interests of college and student. A student naturally has the right to be free of unreasonable search and seizures ... . The college, on the other hand, has an "affirmative obligation" to promulgate and enforce reasonable regulations designed to protect campus order and discipline and to promote an environment consistent with the educational process. The validity of the regulation authorizing search of dormitories thus does not depend on whether a student "waives" his right to Fourth Amendment protection or on whether he has "contracted" it away; rather, its validity is determined by whether the regulation is a reasonable exercise of the college's supervisory duty. In other words, if the regulation-or, in the absence of a regulation, the action of the college authorities-is necessary in aid of the basic responsibility of the institution regarding discipline and maintenance of an "educational atmosphere," then it will be presumed facially reasonable despite the fact that it may infringe to some extent on the outer bounds of the Fourth Amendment rights of students.

State v. Hunter, 831 P.2d 1033, 1035-36 (Utah Ct. App. 1992) (citing Moore v. Student Affairs Commonwealth of Troy State Univ., 284 F.Supp. 725 (M.D. Ala. 1968)).

204. Commonwealth v. Carr, 918 N.E.2d 847 (Mass. App. Ct. 2009), rev'd on other grounds, 936 N.E.2d 883 (Mass. 2010). 
must otherwise fully comply with Fourth Amendment restrictions pertaining to ordinary criminal investigations.

Carr involved a dorm room search that occurred at Boston College, a private university. Under Boston College's "Conditions for Residency," all weapons of any kind, whether licensed or unlicensed and whether real or counterfeit, are prohibited. ${ }^{205}$ After receiving reports that student Daniel Carr had a gun and a knife in his dorm room, resident assistant April Wynn brought the reporting students to campus police, where they repeated the allegations to Sergeant John Derick. ${ }^{206}$ Thereafter, Sergeant Derick, two additional campus police officers, Wynn, and another resident director went to Carr's dorm room and knocked on the door. ${ }^{207}$ When Carr opened the door, Derick entered the room and explained to Carr that he was responding to a report of weapons in the room. ${ }^{208}$

After Derick secured a waiver of Carr's Miranda rights, Carr showed Derick where he had hidden a plastic replica gun that resembled a .45 caliber handgun, which was missing the red tip normally present on such guns. ${ }^{209}$ After Carr produced the gun, Derick asked if there were any more weapons in the room, and Carr's roommate produced a folding buck knife. $^{210}$ Campus police also discovered other similar weapons. ${ }^{211}$ All of these items violated the college's Conditions of Residency, although none appeared to be unlawful. ${ }^{212}$

After finding the reported weapons, the investigating officers sought consent to conduct a more extensive search of the dorm room, and produced a written form including both a "Miranda waiver" and a "Consent to Search." After initial resistance, both Carr and his roommate signed the "Consent to Search" form. During the ensuing search, officers discovered illegal drugs, and arrested Carr and his roommate. ${ }^{213}$

On appeal, the court had to decide three issues: (1) whether the Fourth Amendment's state action requirement was met, thereby triggering Fourth Amendment protections; (2) if so, whether the officers' initial entry into the dorm room was valid; and, finally, (3) whether the roommate's consent, which was the basis for conducting the more extensive dorm room search, was likewise valid.

205. See id. at 849 .

206. Id at 848-49.

207. Id. at 849 .

208. Id.

209. Id. at 849-50.

210. Id. at 850 .

211. Id.

212. See id. at 848-50.

213. See id. at 848-51. 
As to the state action question, the court first noted that the resident assistants would not have been engaged in state action had they entered the dorm room on their own initiative to make a "plain view search" for prohibited items (i.e., as part of an administrative inspection), as "Boston College is a private actor not subject to the constraints of the Fourth Amendment ...."214 The constitutional analysis potentially changed, however, when the resident assistants "enlist[ed] the assistance of the campus police," 215 who can be state actors by virtue of the fact that they are "[s]pecially commissioned officers formally affiliated with the sovereign and possessing authority beyond that of an ordinary citizen ... such as arrest and use of weapons ....,216

Next, the court considered whether the officers' initial entry into the dorm room was lawful. Emphasizing the campus safety concerns that motivated this particular search, the court found that "the initial entry ... to investigate a credible report of a weapon in the room was authorized under the college's 'Conditions of Residency' and did not require a search warrant or consent." 217 Thus, despite having found that the campus police could be governmental actors, the court found that, because the primary purpose of the initial entry "was not in furtherance of a criminal investigative function, but to address a violation of Boston College's policy that prohibited weapons in the dormitory," the initial entry did not violate the Fourth Amendment. ${ }^{218}$

The final issue in the case involved whether the officers obtained valid consent to search the dorm room more extensively, which occurred after the reported weapons that prompted the initial search (a gun and knife) had been located and secured. ${ }^{219}$ According to the court, this particular search, which resulted in the discovery of illegal drugs, "stands on different footing" than the initial entry presumably because the safety concerns that justified the initial search for weapons no longer applied. ${ }^{20}$ For this reason, the court ended its analysis by examining the validity of

214. See Carr, 918 N.E.2d at 851-52.

215. See id. at 852 .

216. See id. Nevertheless, the court declared that "while the Fourth Amendment ... appl[ies] to the conduct of Boston College's campus police, in this circumstance the officers' private function affects the constitutionality of their conduct and renders it reasonable." See id.

217. Id. at 851 .

218. Id. at 852-53. Emphasizing the university's legitimate campus safety concern, the court found that "[ $t]$ he investigation was a legitimate means of protecting the college's property and fulfilling its obligation to provide a safe environment for its residents." Id. at 853 . Further recognizing the lack of police instigation as a critical factor, the court emphasized that "[ $t]$ he resident director enlisted police assistance, not vice versa." Id.

219. Id. at 853 .

220. See id. at 854 . 
the purported consent, a warrant exception that allegedly authorized the additional search. ${ }^{221}$ Although determining the purported consent's validity was necessary to resolve whether the drugs should be suppressed, the court's analysis of that particular issue is not relevant here. Rather, what matters is the court's recognition of the fact that, once the campus safety concerns had evaporated, the validity of the additional search conducted for a criminal investigative purpose required its own, independent justification.

\section{K-12 AND COllege Student Cell Phone SeARChes After RILEY}

Riley involved a search conducted on the heels of an arrest, which is far removed from the K-12 and college campus setting where searches often occur because of simple rules violations or for routine administrative purposes. Nevertheless, the analogy between searches of adult arrestees and searches of students is strong, as both sets of individuals enjoy limited privacy rights. Moreover, despite acknowledging that arrestees enjoy "diminished privacy interests," Riley found that the "privacy-related concerns" in cell phones' digital data were so substantial that searching such data required a warrant. ${ }^{222}$ This same rationale can be applied to $\mathrm{K}-12$ and college students. Quite simply, if "privacy-related concerns are weighty enough",223 to require a warrant to search the cell phones of arrestees, who have traditionally enjoyed reduced Fourth Amendment protection, then privacy-related concerns may also be weighty enough to conduct the same searches of K-12 and college students, who likewise enjoy reduced Fourth Amendment protection.

Through its lengthy analysis of the privacy concerns inherent in cell phones, Riley left no doubt that cell phones occupy a unique position in Fourth Amendment jurisprudence, and may deserve even greater constitutional protection than what is owed the home. According to Riley, "[a] phone not only contains in digital form many sensitive records previously found in the home," such as bank statements, "it also contains a broad array of private information never found in a home in any form...," such as an Internet search and browsing history or a collection of apps that reveal a person's hobbies and interests. ${ }^{224}$ Cell phones, Riley declared, are like "minicomputers"225 capable of being used for many purposes, such as text and voice communications. ${ }^{226}$

221. Id. at $854-55$.

222. See Riley v. California, 134 S. Ct. $2473,2488-89$ (2014).

223. Id.

224. See id. at $2490-91$.

225. Id. at 2489 .

226. See id. 
Moreover, the storage capacity of modern smart phones is massive and, by analogy to physical searches, is like housing a vast warehouse of information. ${ }^{227}$ Thus, by searching a cell phone, it is possible to aggregate many discrete pieces of private information to essentially reconstruct a person's entire private life. ${ }^{228}$

The privacy concerns in the modern cell phone do not change simply because the phone is used by $\mathrm{K}-12$ and college students as opposed to adults. First, the underlying digital data is the same. In addition, given the extensive use of cell phones by young persons, the volume of data on a young person's phone is likely just as great, if not greater, than that of the typical adult. Thus, the privacy concerns are at a minimum no different, and possibly even weightier. For this reason, even searches of cell phones conducted on public school groundswhere Fourth Amendment protections are typically diminished - may demand enhanced Fourth Amendment protection. Nevertheless, upon considering the underlying reasons for permitting warrantless searches of $\mathrm{K}-12$ and college students, the case for extending Riley to K-12 students becomes problematic.

\section{A. $K-12$ Students}

In $\mathrm{K}-12$ case law, reasonable suspicion is typically required for a search to be reasonable, and judicial oversight generally does not occur. ${ }^{229}$ Accordingly, the question in the $\mathrm{K}-12$ context is simple: whether Riley should be interpreted to require more than reasonable suspicion, and perhaps some type of third-party approval, for an educator to search a child's cell phone.

As noted, the Supreme Court has rejected both the probable cause and warrant requirements for the K-12 context. ${ }^{230}$ In doing so, the T.L.O. Court emphasized the "substantial need of teachers and administrators for freedom to maintain order in the schools," ${ }^{, 231}$ as well as the desire to avoid having them master the subtleties of probable cause, ${ }^{232}$ determining instead that teachers should be permitted to act swiftly "according to the dictates of reason and common sense.,"233 Although these concerns are equally valid in the context of cell phone searches, particularly given the potential for cell phones to disrupt the learning process, the privacy

227. Id.

228. Id

229. See New Jersey v. T.L.O., 469 U.S. 325, 340-42 (1985) (rejecting both the warrant and probable cause requirements for $\mathrm{K}-12$ searches).

230. See id.

231. See id. at 341 .

232. See id.

233. See id. 
concerns on the other side of the scale are far greater than in T.L.O., which involved the less invasive search of a student's purse. ${ }^{234}$ That the enhanced privacy concerns in the modern cell phone vis-à-vis a student's personal belongings should alter the reasonableness balancing cannot be questioned. Indeed, on several occasions, Riley compared the privacy interests in bags, purses, and the like and found them far less substantial than those associated with the modern cell phone. ${ }^{235}$ The only question, therefore, is whether the cell phone's increased privacy concerns disrupt the reasonableness balance so much as to alter the constitutional requirements for searching a student's phone.

The argument against extending Riley to the K-12 setting is straightforward. First, as the T.L.O. Court acknowledged, the warrant requirement is particularly unsuited to the $\mathrm{K}-12$ school environment, where "swift and informal disciplinary procedures" are required. ${ }^{236}$ Second, Riley involved a search incident to an adult's lawful arrest for an offense having nothing to do with his cell phone. These circumstances are different than the typical $\mathrm{K}-12$ cell phone search case, where cell phones are ordinarily searched as the result of a phone being used by a young child to effectuate a suspected violation of school policy. Third, warrant exception precedents ordinarily do not apply to other warrant exception scenarios. In Fourth Amendment jurisprudence, where context matters, narrow holdings should be applied narrowly. ${ }^{237}$ Finally, there are few, if any, cases to date applying Riley to the search of a K-12 student's cell phone, and at least one court has rejected the argument outright (although the decision could be overturned on appeal). ${ }^{238}$

234. See id. at 328.

235. See Riley v. California, 134 S. Ct. 2473, 2488-89 (2014) ("The United States asserts that a search of all data stored on a cell phone is 'materially indistinguishable' from searches of these sorts of physical items. That is like saying a ride on horseback is materially indistinguishable from a flight to the moon. Both are ways of getting from point $A$ to point $B$, but little else justifies lumping them together. Modern cell phones, as a category, implicate privacy concerns far beyond those implicated by the search of a cigarette pack, a wallet, or a purse.") (internal citations omitted); id. at 2490 ("[I]t is no exaggeration to say that many of the more than $90 \%$ of American adults who own a cell phone keep on their person a digital record of nearly every aspect of their lives-from the mundane to the intimate. Allowing the police to scrutinize such records on a routine basis is quite different from allowing them to search a personal item or two in the occasional case.") (internal citations omitted).

236. T.L.O., 469 U.S. at 340.

237. See id. at 337 ("Although the underlying command of the Fourth Amendment is always that searches and seizures be reasonable, what is reasonable depends on the context within which a search takes place.").

238. The California Court of Appeal recently rejected the suggestion of applying Riley to the search of a high school student's cell phone in In re Rafael C, $245 \mathrm{Cal}$. App. 4th 1288, 1297-1300 (2016). However, this opinion was subsequently superseded and will be reviewed by the California Supreme Court. See In re R.C., 372 P.3d 903 (Cal. 2016) (granting petition for review). 
Having also considered Riley's impact on K-12 student cell phone searches, Professor Bernard James argues that the T.L.O. framework is alone sufficient to produce the additional rigor needed for such searches. ${ }^{239}$ Professor James points to the Court's application of the T.L.O. framework in Safford, which involved a strip search, and argues that "[o]ne must logically conclude that the higher-order privacy interest of students to resist a strip search is equal to (if not greater than) the higher expectation of privacy students now possess in the digital contents of their cell phones."240 According to Professor James, if the T.L.O. framework can guard against an unreasonable strip search, it can likewise guard against an unreasonable cell phone search. Regarding warrants, Professor James further argues that T.L.O. is designed to "permanently separate educators from other government officials to whom the Fourth Amendment's warrant requirement would apply," particularly given schools' custodial and tutelary responsibility for children. $^{241}$ As such, he believes that Riley should not alter K-12 cell phone search requirements, warrants should not be required, and the T.L.O. reasonableness framework should continue to govern such searches. ${ }^{242}$

Although I agree with Professor James that the unique custodial and tutelary responsibilities of K-12 educators, combined with their need for freedom from judicial interference, makes the warrant requirement particularly ill-suited in the K-12 setting, I believe there is a middleground solution that would properly balance these governmental interests against the unique privacy interests in cell phones. To strike the necessary balance, I propose that schools adopt an internal system of checks and balances that consists of two stages. Under the first stage of my proposal, the school official seeking to search a phone must first state, in writing, the detailed factual basis for suspecting the phone contains evidence of a violation of law or school rule. Thereafter, an independent school administrator, perhaps the head principal or a school board member, would review the report and, if a sufficient basis for searching the phone exists, would approve the search by affixing his or her signature to the document. This would be akin to an administrative warrant that a head school official must sign before a cell phone may be

239. See James, supra note 4, at 353.

240. See id. at 354 .

241. See id. at 352.

242. Despite arguing that Riley should not alter the T.L.O. reasonableness framework, Professor James acknowledges that "smart devices combine with digital storage technology to create a unique type of personal property" that carries with it "increased rigor of constitutional protections," such that refusing to modify T.L.O. in this context "negates the unique privacy interest of students who take cell phones onto campus." See id. at 351 . 
searched. Also, as in Riley, the phone could be seized for whatever reasonable amount of time is needed to secure the necessary authorization.

Although not all scholars agree on the true purpose of the Fourth Amendment, ${ }^{243}$ at least one supposed purpose is to capture the benefits of separation of powers by requiring independent judicial review and approval before the executive may invade one's privacy. ${ }^{244}$. However, formal judicial approval may do more harm than good in the public school setting. My proposal would obtain the benefits of such review without incurring its costs.

On the one hand, by requiring a second-tier review within the school itself, my proposal would allow schools to develop their own internal set of checks and balances, thereby respecting T.L.O.'s concern with preserving "the swift and informal disciplinary procedures needed in [public] schools," 245 free from undue judicial supervision. On the other hand, my proposal would help ensure that when cell phones are searched, they are examined in a reasonable manner with minimal impact on privacy. Effectuating T.L.O.'s reasonable in its inception requirement, my proposal would require the school official desiring to search a phone to detail the precise factual basis for suspecting the phone will contain evidence that the student has violated or is violating a school rule or the law. ${ }^{246}$ Implementing T.L.O.'s reasonable in scope requirement, my proposal would also require the initiating school official to include in his or her written report a search protocol specifying exactly

243. See Tracey Maclin \& Julia Mirabella, Framing the Fourth, 109 MicH. L. REV. 1049, 1052 (2011) (reporting that the comprehensive Fourth Amendment research of William Cuddihy, who generated the most comprehensive and detailed analysis of the history of search and seizure law, "demonstrates that there was no single meaning of the Fourth Amendment").

244. See Tracey Maclin, Let Sleeping Dogs Lie: Why the Supreme Court Should Leave Fourth Amendment History Unabridged, 82 B.U. L. REV. 895, 941 (2002) (arguing that "[a]lthough the [Fourth] Amendment's text bans only general warrants, the 'larger purpose for which the Framers adopted the text [was] to curb the exercise of discretionary authority by officers"'); Steagald v. United States, 451 U.S. 204, 220 (1981) (stating that "[t]he central objectionable feature of both [the general warrants that had occurred in England and of the writs of assistance used in the Colonies] was that they provided no judicial check on the determination of the executing officials that the evidence available justified an intrusion into any particular home"). But see Amar, supra note 25, at 771-72 (arguing that the Fourth Amendment contains no actual warrant requirement, and that "at times, the Founders viewed judges and certain judicial proceedings with suspicion," adding that the Amendment's Warrant Clause "does not require, presuppose, or even encourage warrants-it limits them" by imposing strict standards on their issuance); Thomas Y. Davies, Recovering the Original Fourth Amendment, 98 MICH. L. REV. 547, 591-619 (1999) (rejecting Amar's reasonableness view of the Fourth Amendment as "based in large measure on erroneous historical premises").

245. See New Jersey v. T.L.O., 469 U.S. 325, 340 (1985).

246. See id. at 342 . 
which parts of the phone will be searched. If a school official has reason to believe a student is violating school rules by sending text messages, for example, only the text message function of the phone may be searched. Likewise, if a school official has reason to suspect a student has been using his or her phone to take photos while in school, only the phone's photographs may be examined. In this manner, my proposal will ensure that cell phone searches, when they occur, are not unnecessarily intrusive. Finally, my proposal would require only relevant head school administrators-those who are engaged in the proposed second-tier review-to receive training on the necessary scope of search limitations, such as, for example, the Sixth Circuit's warning in G.C. that "using a cell phone on school grounds does not automatically trigger an essentially unlimited right . . . to search any content stored on the phone that is not related either substantively or temporally to the infraction." ${ }^{247}$ This, in turn, will spare the vast majority of school officials (such as the teachers who are most likely to observe a cell phone violation) from having to master the relevant legal requirements and case precedents. ${ }^{248}$

In response to the Supreme Court's decision in Riley, and even before Riley in the context of laptop searches, some courts have required detailed search protocols, which are technical documents that explain the actual search methods the government will use to search a cell phone, to ensure that cell phone searches are not unnecessarily intrusive. ${ }^{249}$ Such protocols are designed to prevent general exploratory searches of phones for whatever incriminating evidence may be found. ${ }^{250}$ Some search protocols go even further than the usual particularity requirements, which require mere descriptions of the places to be searched and evidence to be seized, by requiring a description of the precise methods the government will use to find the data on the seized device. ${ }^{251}$

247. G.C. v. Owensboro Pub. Schs., 711 F.3d 623, 633 (6th Cir. 2013).

248. See T.L.O., 469 U.S. at 343.

249. For an excellent summary of this practice, see generally William Clark, Protecting the Privacies of Digital Life: Riley v. California, the Fourth Amendment's Particularity Requirement, and Search Protocols for Cell Phone Search Warrants, 56 B.C. L. REV. 1981 (2015).

250. See Maryland v. Garrison, 480 U.S. 79, 84 (1987) (recognizing that the Fourth Amendment's particularity requirement "ensures that [a] search will be carefully tailored to its justifications, and will not take on the character of the wide-ranging exploratory searches the Framers intended to prohibit"); United States v. Carey, 172 F.3d 1268, 1272 (10th Cir. 1999) (recognizing that the purpose of the particularity requirement is "to prevent a general exploratory rummaging in a person's belongings").

251. See In re Search of Apple iPhone, 31 F. Supp. 3d 159, 166-68 (D.D.C. 2014) (requiring a detailed search protocol before authorizing the search of an iPhone); see also Clark, supra note 249 , at $1990-91$ (discussing this issue). 
In light of the special concerns inherent in the K-12 school setting, my proposal does not require a description of the actual methods school officials will employ when searching a phone. Rather, it merely requires a basic search protocol limiting cell phone searches to certain types of data, such as text or image files. ${ }^{252}$ Such basic scope requirements are, in my view, sufficient to ensure that cell phone searches are "not excessively intrusive in light of the ... nature of the infraction,",253 thereby preventing the type of search struck down in Klump. ${ }^{254}$

\section{B. College Students}

Although college students are treated similarly to K-12 students at times, particularly with respect to administrative inspections of college living quarters, the campus safety concerns that underlie those rulings typically do not apply to a cell phone's digital contents. Quite simply, a phone's digital data, unlike a weapon that may be hidden in a student's dorm room, cannot harm anyone. ${ }^{255}$ Moreover, unlike administrative sweeps of dorm rooms for health and safety purposes, it is difficult to imagine a scenario where college students' cell phones could be reasonably "inspected" for similar administrative purposes. Thus, routinely searching such devices would not enhance the educational environment. Finally, even when a university official happens to come across a cell phone while conducting an otherwise permissible administrative inspection, which is unlikely given that most students tend to carry their phones with them, ${ }^{256}$ it is difficult to imagine circumstances that would permit an immediate inspection of the phone's digital data.

Take, for example, the hypothetical scenario of Sam, a student who lives in a university owned and operated dorm room at Indiana University, a public university. When Sam enrolled at Indiana University, he signed a form consenting to the provisions of the Indiana

252. Cf. In re Search of 3817 W. West End, 321 F. Supp. 2d 953, 957-59 (N.D. IIl. 2004) (finding that when issuing a warrant authorizing the seizure and search of a computer, a judge may require the government to set forth a search protocol that attempts to confine the search to only those areas where there is probable cause to believe evidence might be found, which may include "limit[ations] by date range; doing key word searches; limiting the search to text files or graphics files; and focusing on [only select] software programs").

253. See James, supra note 4 , at 342.

254. See supra notes 184-194 and accompanying text.

255. See Riley v. California, 134 S. Ct. 2473, 2485 (2014) (addressing this issue and basing its holding, in part, on the fact that "[d]igital data stored on a cell phone ... can endanger no one").

256. See id. at 2490 (reporting that, "[a]ccording to one recent poll, nearly threequarters of smart phone users report being within five feet of their phones most of the time, with $12 \%$ admitting that they even use their phones in the shower"). 
University Student Handbook, which authorizes certain administrative health and safety inspections of campus dorm rooms. After receiving reports of an unauthorized cat on the fifth floor of Sam's dorm room, resident assistant Jimmy randomly inspects various rooms near where the cat sounds were heard. When Jimmy enters Sam's dorm room, he notices a strange light emanating from Sam's closet and thinks he smells cat litter. Jimmy then opens the closet door and discovers dozens of plastic bags full of marijuana. He also observes what appears to be a customer list on a pad of paper lying next to the plastic bags, which lists names and amounts of "money owed," along with a cell phone.

In this particular context, one might argue that the phone's contents should be immediately searchable without a warrant, at least the portions of the phone that might contain evidence related to drug distribution. However, as Carr demonstrates, ${ }^{257}$ it is one thing for the resident assistant to inadvertently discover evidence of a crime while carrying out a permissible administrative inspection, such as the marijuana lying in plain view in Sam's closet, and quite another to expand the search's scope into a full-blown criminal investigation having nothing to do with the missing cat. ${ }^{258}$

There are also inherent difficulties in limiting the scope of a cell phone search in an appropriate manner. For this reason, Riley rejected the Government's proposal that would have allowed warrantless searches of only the particular areas of a phone that might contain evidence related to drug distribution. ${ }^{259}$ In its Supreme Court brief in Riley, the Government argued that a warrantless search "would be objectively

257. See supra notes $205-221$ and accompanying text.

258. This hypothetical is adapted from Commonwealth v. Neilson, 666 N.E.2d 984 (Mass. App. Ct. 1996), and Medlock v. Trs. of Ind. Univ., No. 1:11-CV-00977-TWP, 2011 WL 4068453 (S.D. Ind. Sept. 13, 2011). The first issue in a case such as this would be whether the resident assistant's initial entry into the dorm room was permissible. On these facts, it likely was. Colleges and universities have a duty to insure the safety of their students, who reside in residence halls around campus, and conducting health and safety inspections of dorm rooms helps achieve this goal. Here, the resident assistant entered Sam's dorm room for the sole purpose of administering a health and safety inspection in accordance with reasonable university regulations. Thus, the resident assistant was likely justified in entering the dorm room and discovering the evidence lying in plain view. See Neilson, 666 N.E.2d at 987 (upholding resident assistant's initial entry of dorm room on similar facts because the initial entry was "intended to enforce a legitimate health and safety rule that related to the college's function as an educational institution," but striking down a subsequent, more extensive search of the room by campus police when the purpose shifted to a search for evidence of crime); Medlock, 2011 WL 4068453, at *5 (finding a resident assistant's initial entry of a student's dorm room, where he discovered drugs in plain view, not to violate the Fourth Amendment when performed for the purpose of administering a health and safety inspection in accordance with school regulations).

259. See Riley, 134 S. Ct. at 2492. 
reasonable if an officer has reason to believe the phone contains evidence of the offense of arrest." 260 The Government further argued that " $[t]$ he scope of that search would depend on the nature of the offense."261 The Government suggested that drug traffickers, for example, could "reasonably be expected to have evidence related to their transactions stored in the areas of the phone concerned with its communication functions-the 'call log, contacts list, text messages, and emails," such that a search of these particular areas would be reasonable. ${ }^{262}$ Riley rejected this argument, however, because even limited rights to search a phone's contents "would impose few meaningful constraints on officers" and be practically unworkable. ${ }^{263}$ As other courts have noted, digital data is often so "intermingled" within a device that only the tightest limitations on scope will suffice to prevent a general exploratory rummaging of whatever evidence the phone might contain. ${ }^{264}$

In short, as Chimel, Belton, Gant, and Riley collectively establish, warrants may be dispensed with only when the justifications for the particular warrant exception at issue apply. ${ }^{265}$ In the context of college student cell phones, the underlying campus safety concern that justifies many warrantless searches on college campuses (or any other legitimate administrative objective) simply does not apply. Although litigants have argued that the lesser protections afforded K-12 students should be expanded to the college setting, ${ }^{266}$ the vast majority of college students are adults, over the age of 18 , such that the unique educational aspects of $\mathrm{K}-12$ education do not apply. Accordingly, it is far more likely that the Court would impose strict probable cause and warrant requirements, similar to Riley, to searches of college students' cell phones.

260. See Brief for the United States at 53, United States v. Wurie, 134 S. Ct. 2473 (2014) (No. 13-212), 2014 WL 828012.

261. Id.

262. Id.

263. See Riley, 134 S. Ct. at 2492.

264. See In re Search of 3817 W. West End, 321 F. Supp. 2d 953, $957-58$ (N.D. Ill. 2004).

265. See generally Riley, 134 S. Ct. at 2473-95; Arizona v. Gant, 556 U.S. 332 (2009); New York v. Belton, 453 U.S. 454 (1981); Chimel v. California, 395 U.S. 752 (1969).

266. See Commonwealth v. Neilson, 666 N.E.2d 984, 986 (Mass. App. Ct. 1996) (noting the argument and stating that "[a]lthough the courts that have examined the issue are split on whether the Fourth Amendment requires probable cause and a warrant in college searches, when police are involved and the evidence obtained is to be used in a criminal proceeding, courts generally require probable cause and a warrant, absent express consent or exigent circumstances"). 


\section{CONCLUSION}

This article has considered the analogy between cell phone searches of arrestees and similar searches of K-12 and college students. As with ordinary adults, college students have a general right to privacy, whereas colleges have an obligation to provide a safe campus and effective learning environment. In traditional Fourth Amendment analysis, the probable cause requirement strikes a balance between these competing interests and is the practical safeguard that prevents arbitrary intrusion by the government. However, on the college campus, neither probable cause nor warrants are required to conduct administrative inspections, particularly those designed to ensure a safe and effective learning environment, which are ordinarily reasonable given their non-criminal focus. As argued above, there are very few, if any, imaginable scenarios where the search of a college student's cell phone would fit comfortably within this rationale. Moreover, as adults, college students deserve the same protections in their cell phones enjoyed by the adult arrestees in Riley: the full protection of a warrant and probable cause.

The case for K-12 students is different. On the one hand, the Supreme Court has declared that the warrant and probable cause requirements are not well suited to the K-12 context. On the other hand, Riley's extensive discussion of the unique privacy concerns associated with the modern cell phone cannot be ignored. Thus, it is less clear how to properly strike the balance between school officials' legitimate needs to maintain order and discipline in the K-12 context and school children's legitimate expectations of privacy in their cell phones. The proposal set forth in this article recognizes the unique needs of $\mathrm{K}-12$ school officials without unduly interposing the judiciary in their educational pursuits, while simultaneously affording the greater protection in school children's cell phones Riley demands. 
